\title{
Limbal Stem Cell Transplantation and Corneal Neovascularization
}

\author{
Kishore Reddy Katikireddy ${ }^{1}$ and Jurkunas V. Ula ${ }^{1,2}$ \\ ${ }^{1}$ Schepens Eye Research Institute \\ ${ }^{2}$ Massachusetts Eye and Ear Infirmary, Harvard Medical School
}

USA

\section{Introduction}

The human ocular surface spans from the conjunctiva to the cornea and plays a critical role in visual perception. Cornea, the anterior portion of the eye, is transparent and provides the eye with two-thirds of its focusing power and protection of ocular integrity. The cornea consists of five main layers, namely, corneal epithelium, Bowman's layer, corneal stroma, Descemet's membrane and corneal endothelium.

The outermost layer of the cornea, which is exposed to the external environment, is the corneal epithelium. Corneal epithelial integrity and transparency are maintained by somatic stem cells (SC) that reside in the limbus. The limbus, an anatomical structure 1-2 $\mathrm{mm}$ wide, circumscribes the peripheral cornea and separates it from the conjunctiva (Cotsarelis et al., 1989, Davanger and Evensen, 1971) (Figure 1). Any damage to the ocular surface by burns, or various infections, can threaten vision. The most insidious of such damaging conditions is limbal stem cell deficiency (LSCD). Clinical signs of LSCD include corneal vascularization, chronic stromal inflammation, ingrowth of conjunctival epithelium onto the corneal surface and persistent epithelial defects (Lavker et al., 2004). Primary limbal stem cell deficiency is associated with aniridia and ectodermal dysplasia. Acquired limbal stem cell deficiency has been associated with inflammatory conditions (Stevens-Johnson syndrome (SJS), ocular cicatricial pemphigoid), ocular trauma (chemical and thermal burns), contact lens wear, corneal infection, neoplasia, peripheral ulcerative corneal disease and neurotrophic keratopathy (Dua et al., 2000, Jeng et al., 2011). Corneal stem cells and/or their niche are known to play important anti-angiogenic and anti-inflamatory roles in maintaining a normal corneal microenvironment, the destruction of which in LSCD, tips the balance toward pro-angiogenic conditions (Lim et al., 2009).

For a long time, the primary treatment for LSCD has been transplantation of healthy keratolimbal tissue from autologous, allogenic, or cadaveric sources. In the late 1990s, cultured, autologous, limbal epithelial cell implants were used successfully to improve vision in two patients with chemical injury-induced LSCD (Pellegrini et al., 1997). Since then, transplantation of cultivated epithelial (stem) cells has become a treatment of choice for numerous LSCD patients worldwide. While the outcomes are promising, the variability of methodologies used to expand the cells, points to an underlying need for better standardization of ex vivo cultivation-based therapies and their outcome measures (Sangwan et al., 2005, Ti et al., 2004, Grueterich et al., 2002b, Kolli et al., 2010). 


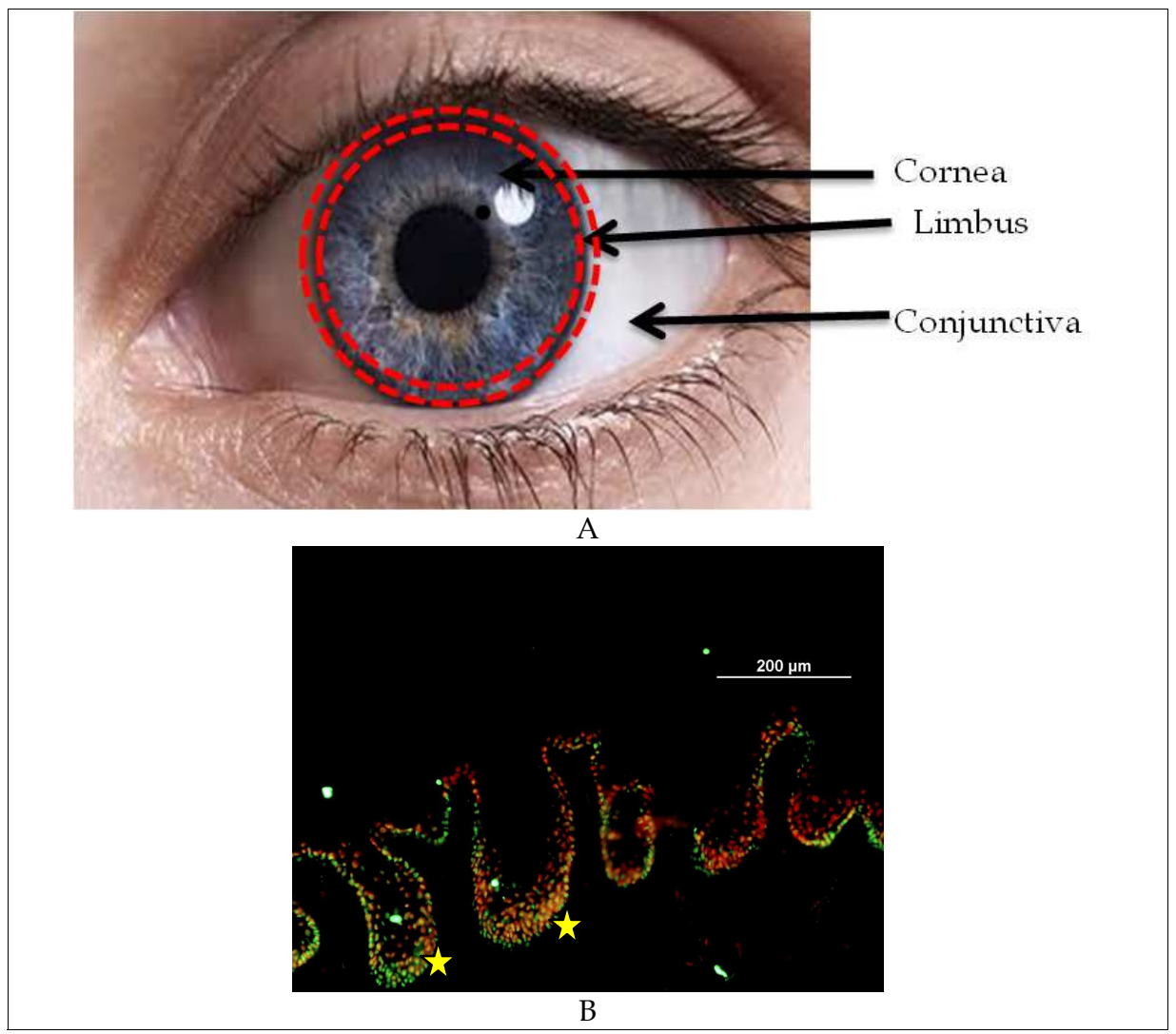

Fig. 1. (A) Photograph of the front of the human eye. The cornea, which is clear, can be seen at the front of the eye highlighted by the light reflections. The cornea is continuous with the limbus, the narrow band of tissue found encircling the cornea. The limbus is continuous with the conjunctiva and its underlying sclera, together forming the anterior portion of the eye. (B) Cross section of human limbal palisades of Vogt.

This chapter provides a general update on LSCD pathogenesis, the key role of stem cells and their niche in maintaining corneal homeostasis and avascularity and a general update on LSCD pathogenesis. An overview of different methodologies used for ex vivo stem cell expansion will shed some light on the future of cell-based therapy for LSCD patients.

\section{What defines limbal stem cell niche}

The ocular surface is anatomically composed of the entire epithelial surface of the cornea, limbus and conjunctiva, and is physically continuous with the eyelids and adenexa. The limbal epithelium, which separates the corneal epithelium from the conjunctival epithelium, is made up of a nonkeratinizing, stratified squamous epithelium, which is much thicker, up to 10 cell layers, than the central corneal epithelium. Moreover, limbal epithelium is thought to contain the source of the stem cells (SC) that serve as the source of corneal epithelial cell 
renewal and provide a barrier between conjunctival and corneal epithelia. These cells are known as corneal epithelial SCs or limbal stem cells (LSCs). In addition to intrinsic factors (i.e., characteristics inherent to the stem cells), extrinsic influences from the microenvironment surrounding the stem cells may also play a role in corneal cell renewal (Barros et al., 1995, Morrison et al., 1997, Tseng, 1996), as discussed below.

\subsection{Limbal microenvironment and stem cell properties}

Within the limbus, LSCs are thought to reside in a stem cell niche, which maintains them in their undifferentiated state. This stem cell niche is anatomically denoted as the palisades of Vogt. The palisades of Vogt are radial infoldings (Figure $1 \mathrm{~B}$ ) located at the limbo-corneal junction, extending outwards of 1-2 mm from that junction (Goldberg and Bron, 1982); a anatomical feature unique to the human eye that can be used as a clinical marker indicating the presence of corneal epithelial stem cells. Davenger and Evensen (1971) and Bron (1973) reported the significant characterizations of the palisades of Vogt in 1971 (Davanger and Evensen, 1971, Bron, 1973). The authors observed heavily pigmented epithelium migrating in lines from the limbus to the central cornea in response to corneal epithelial defects.

\subsubsection{Characterization and microenvironment of the palisades of Vogt}

The limbal basement membrane differs from that of the cornea that undulates, with pegs of stroma extending upward and interconnecting with anchoring fibrils that link to the basement membrane (Gipson, 1989). This structure could provide resident stem cells with an adherent niche, protecting them from injury and movement within their microenvironment. Differences in the composition of the limbal and central corneal basement membranes have been observed, and these are thought to play a role in the maintenance of their respective populations of epithelial cells. Moreover the LSC niche lies beneath a number of cell layers where oxygen tension is likely to be lower. Limbal cells are in close proximity to a blood supply and have access to survival factors such as keratinocyte growth factor (KGF), IL-6 and components of basement membrane unavailable to cells of the central cornea. Interestingly, hypoxic ex vivo conditions have been found to produce larger, less differentiated limbal epithelial cell colonies, suggesting that low oxygen levels may induce selective proliferation of undifferentiated cells (Miyashita et al., 2007).

Photomicrographic, angiographic and histological studies have demonstrated the fibrovascular nature of the palisades and the presence of "ridges of thickened epithelium" in the interpalisade zone (Goldberg and Bron, 1982, Townsend, 1991). Confocal microscopy along with scanning electron microscopy (SEM) provides the opportunity to optically section the corneal limbus and create 3D reconstructions of the tissue (Romano et al., 2003, Shortt et al., 2007). This approach allows identification of previously unrecognized candidates for the LSC niche, limbal crypts (LCs) and focal stromal projections (FSPs), and has significantly advanced understanding of the structure of this adult stem cell niche.

\subsubsection{Asymmetric cell division}

Adult SCs exist in an optimal microenvironment or 'niche' that promotes their maintenance in an undifferentiated state (Fuchs et al., 2004). When SCs undergo asymmetric division, only one of the daughter cells can re-enter the niche to replenish the SC population (Figure 2). The other cell loses the protection of the niche and is destined to differentiate and become a transient amplifying cell (TAC). The role of the TAC is to divide at an exponential rate in 


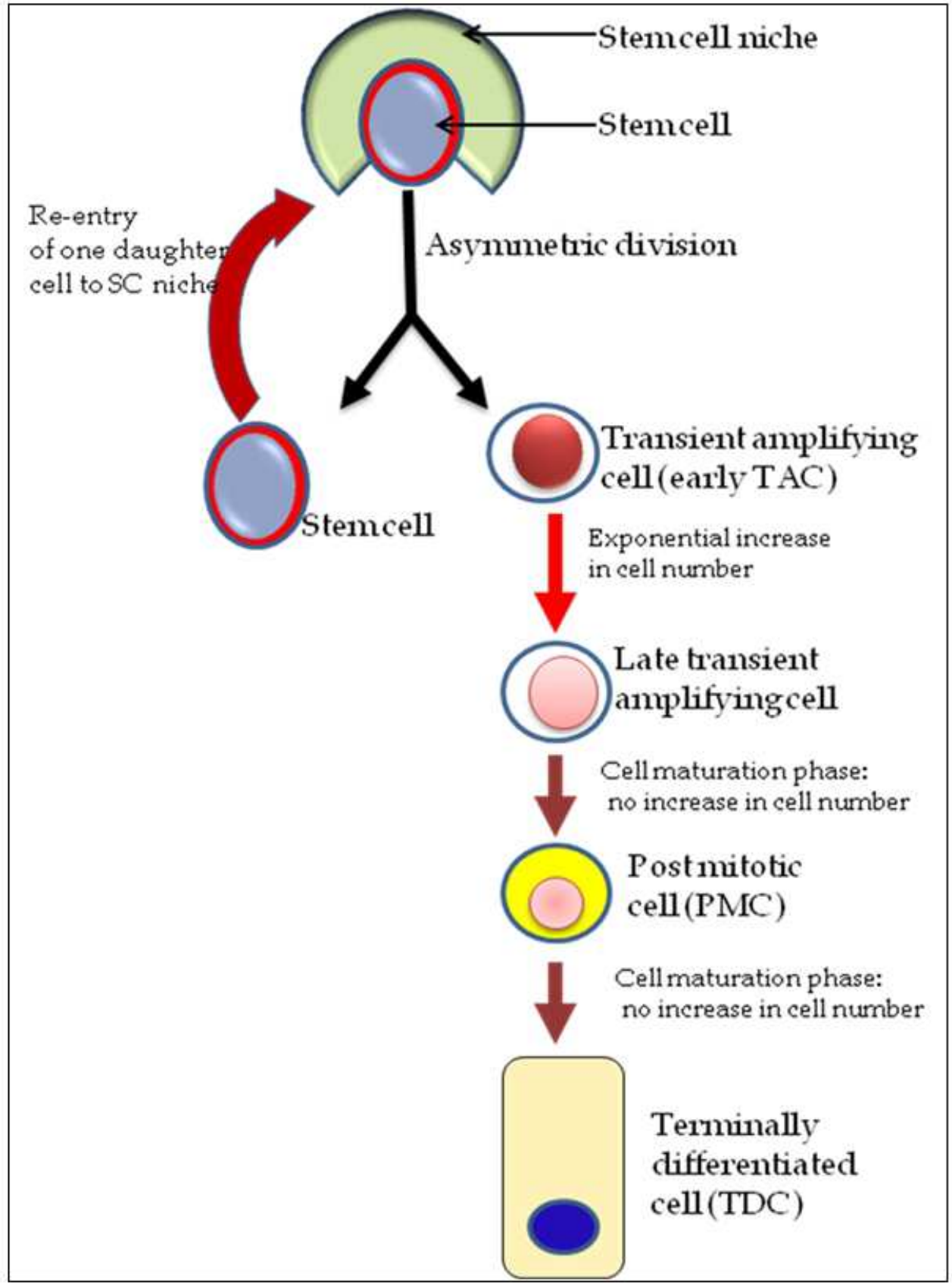

Fig. 2. Schematic diagram of the SC hierarchy. Modified from (Drug Discovery Today. Volume 15,Number 7/8.April 2010. 
order to provide increased cell numbers. The ability of the TAC to multiply is limited and will eventually differentiate into a post-mitotic cell that can no longer multiply (Cotsarelis et al., 1989). The PMCs are committed to cellular differentiation and mature to form terminally differentiated cells that represent the final phenotypic expression of the tissue type. These mechanisms are essential for the understanding of normal stem cell function and homeostasis. Moreover the LSC population is positioned to be influenced by a wide variety of cells. These influences include cell-to-cell contact, cell-extracellular matrix contact, and paracrine signalling factors and their receptors, and they from adjacent conjunctival epithelial cells and fibroblasts, corneal epithelium and fibroblasts, limbal blood vessels, limbal melanocytes, corneal nerves and Langerhans cells. The limbal fibroblasts in the underlying stroma are heterogeneous and express secreted protein acidic and rich in cysteine (SPARC), which may contribute to LSC adhesion (Shimmura et al., 2006).

\subsubsection{Cell signalling}

Cytokine of the cornea and limbus implied specific differences in their microenvironments, suggesting fibroblast-mediated paracrine regulation of LSCs. For example, corneal fibroblasts release hepatocyte growth factor (HGF), whereas limbal fibroblasts secrete keratinocyte growth factor (KGF) (Sotozono et al., 1994). Most importantly, epithelial cells at the basal layer of the limbus express high levels of the KGF-R, in contrast to central corneal epithelium, which expresses fewer of this receptor. KGF is a potent stimulator of proliferation in epithelial cells, and its presence in the limbus results in the proliferation of LSCs and TACs (Sotozono et al., 1994). HGF is known to stimulate the migration of epithelial cells, and it has been proposed that HGF aids the migration of new TACs produced at the limbus through the action of KGF (Wilson et al., 1994). The basement membrane separates the LSC from stroma and, thus modulates growth factors and cytokines involved in LSC regulation and function (Klenkler and Sheardown, 2004).

Sonic hedgehog, Wnt/ $\beta$-catenin, TGF- $\beta$ and Notch signalling pathways have all been implicated in niche control of stem cells; however, little is known of their potential roles in the LSC niche. Lack of Dkk2, leads to increased Wnt/ $\beta$-catenin signalling in limbal stroma. This demonstrates the importance of limbal niche control over LSC differentiation during development. PAX6 expression is also lost in the corneal epithelial cells of mutant mice, suggesting the control downstream of Dkk2 (Mukhopadhyay et al., 2006). PAX6 deficiency leads to aniridia, resulting in turn to impaired corneal epithelial function and eventual LSC failure, which may be due to altered niche development. A more recent study by SchlotzerSchrehardt et al. found patchy immunolocalization of the laminin $\gamma 3$ chain, BM40/SPARC and tenancin $C$, which were also found to colocalize with ABCG2/p63/K19-positive cell clusters. These factors may be involved in retaining cell stemness (Schlotzer-Schrehardt et al., 2007).

\section{Insult to the niche and corneal limbal stem cell deficiency}

Corneal blindness is a condition currently affecting about 10 million people worldwide (Klenkler et al., 2005). Corneal damage and disease can be a result of LSC deficiency, which can be heritable or acquired. Limbal stem cell deficiency (LSCD) results from the loss or dysfunction of LSC, most often because of injury or inflammation (Dua et al., 2000). When 
the corneal limbal stem cells are depleted below a certain threshold, the cornea becomes covered by an abnormal conjunctiva-like epithelium, a process termed "conjunctivalization." As a result of LSC deficiency, neovascularization, chronic inflammation, recurrent erosions, ulceration and stromal scarring can occur, causing painful vision loss (Holland and Schwartz, 1996, Kenyon and Tseng, 1989).

LSCD is classified as either primary or secondary. Primary LSCD is characterized by the absence of identifiable external factors and an insufficient microenvironment to support the LSCs. Primary LCSD is seen in hereditary aniridia, congenital erythrokeratoderma, keratitis with multiple endocrine deficiencies and inadequate nutrition or cytokine supply, neurotrophic keratopathy, peripheral inflammation, and sclerocornea (Puangsricharern and Tseng, 1995). Dysfunction/poor regulation of stromal microenvironment of limbal epithelial SCs results in gradual loss of the SC population or TAC generation and amplification.

Secondary LSCD occurs following the destruction of LSCs by external factors such as trauma, chemical-acid or alkali or thermal injuries (Tseng, 1985), or ultraviolet and ionizing radiation (Fujishima et al., 1996); systemic conditions such as Stevens-Johnson Syndrome (SJS), or ocular cicatricial pemphigoid (OCP) (Pfister, 1994).

\subsection{Clinical conditions}

The corneal epithelium cannot be maintained or renewed in eyes with LSCD, and leads to chronic epithelial defects. As the condition progresses, punctate epithelial keratopathy may develop and lead to severe epithelial defect. Due to decreased healing ability, corneal epithelial defects may become persistent, which can lead to stromal scarring, ulceration, and perforation (Puangsricharern and Tseng, 1995). Conjunctivalization of the cornea may occur, where the corneal epithelium is replaced with a conjunctival epithelial phenotype (Huang and Tseng, 1991). Loose intercellular connections result in stippled or late staining with fluorescein, and a lack of normal hemidesmosomal attachments at the base of corneal epithelial cells (Dua and Forrester, 1990). The cause of the LSCD often dictates whether the disease is unilateral or bilateral (i.e., affecting one eye or both).

\subsubsection{Pathology of limbal stem cell deficiency and histologic, ultrastructural studies}

Currently, diagnosis of LSCD is based on clinical evaluation, although clinical signs and symptoms of LSCD are nonspecific and common to several ocular surface diseases. The disease manifests as epithelial defects, chronic inflammation, keratitis, vascularization, and fibrosis, ultimately resulting in corneal blindness. In the absence of specific markers for limbal stem cells, identification of conjunctival goblet cells on the corneal surface is used to demonstrate conjunctival epithelial ingrowth or growth of epithelia on the corneal surface and to confirm the diagnosis of LSCD (Tseng, 1989, Dua and Forrester, 1990, Pfister, 1994).

Normal limbal architecture, with rows of palisades and a perilimbal vascular arcade, is usually best defined at the superior and inferior limbus. Definition of the palisades is less distinct nasally and temporally. Delicate changes such as staining of conjunctiva-derived cells on and across the limbus, which may be associated with a persistent epithelial defect, and other changes such as scarring, vascularization, or limbal hyperaemia, indicating chronic inflammation, can be seen in the early stages. SC deficiency following mild injury, a superficial or a disease process is slowly progressive, and loss of a segment of limbal epithelium may occur without significant damage to the substratum. A sheet of 
conjunctival/metaplastic epithelium without any notable vascularization consequently covers the cornea (Dua, 1998). Other pathological conditions resulting from LSCD are abnormal conjunctival/metaplastic epithelium; tags of loose epithelium filaments with mucus, and recurrent erosions, with unstable tear film that readily takes up fluorescein dye (Huang and Tseng, 1991).

In moderate to severe cases of SC deficiency, superficial and/or deep vascularization of the cornea occurs. Initially it is restricted to the segment with SC deficiency, but in later stages, the entire circumference may become involved. However, in moderate to severe cases of SC deficiency, epithelial cover of the denuded cornea is associated with encroachment of fibrovascular tissue of varying thicknesses (Kenyon and Tseng, 1989). In human eyes, ocular surface insult from chemical burns may go beyond damage to the limbal tissue, leading to long-term ocular surface damage. This damage may include distortion and dysfunction of proximal or distal bulbar conjunctiva, tarsal conjunctiva, and anterior orbital tissues, resulting in abnormalities in surface mucous secretion and wetting, cicatrizing of conjunctiva, symblepharon, and entropion (McCulley, 1990, McCulley et al., 1983, Grant and Kern, 1955).

In summary, alkali burns are the commonest cause of severe LSCD, producing longstanding and persistent changes, like epithelial hyperplasia, fibrosis, and inflammation of the ocular surface. Presence of goblet cells on the cornea confirms the diagnosis of LSCD, but their absence does not rule it out, and correlates presence or absence with prolonged interval and squamous metaplasia of the entire surface in such cases (Fatima et al., 2008).

\subsubsection{Accompanying neovascularization}

The cornea is avascular, but a wide variety of insults can cause capillary invasion from the limbal vascular plexus. This process of new blood vessel formation is termed as corneal neovascularization (NV) (Chang et al., 2001, Takahashi et al., 1999). The three major categories of corneal NV are superficial vascularization, fibrovascular pannus, and deep stromal vascularization. Superficial vascularization rarely causes a decrease in vision; however, the latter two types of corneal NV can lead to significant loss of vision if they involve the visual axis. The most frequent causes of corneal angiogenesis are injury and defective limbal stem cells.

\section{Putative mechanisms of LSCD and corneal neovascularization}

There is a delicate balance between angiogenic and anti-angiogenic factors in the cornea, which determines its vascularity or lack thereof. The normal cornea is avascular, and corneal epithelial stem cells may play a significant role in maintaining the angiogenic balance in favour of avascularity. Nevertheless, there are numerous pro-angiogenic factors that play key roles in pathologic corneal NV. A comprehensive review of all the factors was described by Lim et.al, and included key factors and their possible mechanisms of action (Lim et al., 2009).

\subsection{Angiogenic factors and anti-angiogenic factors}

Vascular endothelial growth factor (VEGF) is a protein that acts as a mitogen for vascular endothelial cells, stimulating these cells to divide and multiply. The most important member 
of this group is VEGF-A, which has been shown to stimulate endothelial cell proliferation and migration. It also increases microvascular permeability. In rats with surgically induced LSCD, high levels of VEGF correlated with inflammation and corneal NV. The corneal NV was suppressed with the addition of anti-VEGF antibody (Amano et al., 1998). Other members of this family include VEGF-B, VEGF-C, VEGF-D, and placenta growth factor.

Inflammatory cytokines, chemokines, and cell adhesion molecules (CAMs) play a significant role in inflammatory cell infiltration and angiogenesis. The inflammatory cytokine interleukin-1 (IL-1) interacts directly with endothelial cells to stimulate migration and proliferation. IL-6 can stimulate corneal and inflammatory cells, in a paracrine manner, to secrete VEGF (Biswas et al., 2006). Tumor necrosis factor- $\alpha$ (TNF- $\alpha$ ) enhances leukocyte infiltration (Yoshida et al., 1997). Chemokines are a family of secreted proteins that act as chemoattractants for inflammatory cells through activation of chemokine receptors. They may also enhance endothelial cell chemotaxis and proliferation (Berger et al., 1999). The chemokines IL-8 (Strieter et al., 1992, Koch et al., 1992) and monocyte chemoattractant-1 (MCP-1) (Goede et al., 1999) have been shown to induce corneal NV in rabbit corneas. Cell adhesion molecules (CAMs) are proteins located on the cell surface involved in binding with other cells or with the extracellular matrix. They facilitate inflammatory cell infiltration into the corneal stroma by mediating the rolling, adhesion, or trans-endothelial migration of leukocytes (Vaporciyan et al., 1993). Fibroblast growth factors (FGF) are a family of heparinbinding peptides that are expressed in tissues during angiogenesis, cellular differentiation, mitogenesis, and wound repair. Basic fibroblast growth factor (bFGF) is an angiogenic factor that exhibits differential binding of vascular basement membranes in newly formed corneal vessels, based on degree of maturation of the vessels (Soubrane et al., 1990).

Several anti-angiogenic factors are produced by corneal epithelial cells, and a variety of vascular endothelial cell inhibitors including angiostatin, endostatin, restin, neostatin, and thrombospondins. Several of these endogenous anti-angiogenic factors are derived from the proteolysis of larger extracellular matrix proteins that have no intrinsic anti-angiogenic activity. Angiostatin, for example, is derived from the proteolysis of plasminogen. Endostatin is another example, produced by the cleavage of collagen XVIII. It inhibits proliferation (Hanai et al., 2002) and migration (Dhanabal et al., 1999) of endothelial cells (EC), and induces EC apoptosis. It may block the activation and catalytic activity of matrix metalloproteinases (MMPs) (Kim et al., 2000) and interfere with the binding of VEGF to its receptors. Arrestin, canstatin, and tumstatin, derived from collagen IV, also inhibit the proliferation and migration of ECs and induce EC apoptosis. Restin, which is related to endostatin, is produced by the proteolytic cleavage of collagen XV and is believed to inhibit EC migration (Ramchandran et al., 1999). Neostatin, derived from collagen XVIII, and thrombospondin are other inhibitors of EC proliferation.

Avascular tissue-derived factors, such as pigment epithelium-derived factor (PEDF), and angiogenic factor antagonists, such as angiopoetin-2, have been found in the cornea (Karakousis et al., 2001). PEDF and angiopoetin-2 inhibit angiogenesis by inhibiting endothelial cell migration and inducing EC apoptosis.

\subsubsection{Role of matrix metalloproteinases (MMPs)}

Matrix metalloproteinases (MMPs) are a family of zinc-dependent proteases. They are commonly categorized as collagenases, gelatinases, matrilysins, or membrane-type MMPs, 
and they play a role in the proteolytic processes involved in angiogenesis (Chang et al., 2001). Their action is inhibited by tissue inhibitors of matrix metalloproteinases (TIMPs). Some are involved in the cleavage process that generates the anti-angiogenic factors angiostatin and endostatin. Plasminogen activator inhibitors inhibit tissue plasminogen activator (tPA) and urokinase plasminogen activator ( $\mathrm{uPA})$, the activators of plasminogen, thereby preventing fibrinolysis and the physiologic breakdown of blood clots.

In response to corneal injury, lipid mediators are released from cell membranes. Platelet activating factor (PAF) is a lipid mediator that facilitates endothelial cell migration through the cornea via increased expression of VEGF (Tao et al., 1996), MMP-9 (Tao et al., 1995), and uPA (Tao et al., 1996). Another important lipid mediator is 12(R)-HETrE, an arachidonic acid metabolite that binds to limbal endothelial cells and causes endothelial mitogenesis and neovascularization (Stoltz and Schwartzman, 1997).

\subsubsection{Animal disease models}

Development of experimental animal models to study ocular NV have been useful in understanding its mechanisms and pathogenesis, as well as to developing potential therapeutic modalities. For example, this basic research led to the discovery of new therapeutic targets for pathologic ocular NV (Barouch and Miller, 2006). In the field of neovascular research, the testing of angiogenic and anti-angiogenic substances relies heavily on the sensitivity and specificity of in vivo and ex vivo bioassays.

Several corneal angiogenesis models in the rabbit have been described, including direct intrastromal injections of substances like heparin-copper complex (Alessandri et al., 1983), induced chemical or thermal injury (Deutsch and Hughes, 1979, Korey et al., 1977), and intrastromal tumor implantation (Gimbrone et al., 1974). The cornea suture model created in mice and rabbits simulate a clinical scenario and are not expensive. However, models inducing an inflammatory component have disadvantages that are surgery dependent and yield highly variable responses. Recently developed micropocket assay models are not expensive, less time consuming; however, they are surgery dependent and yield highly variable responses (Rogers et al., 2007, Loughman et al., 1996).

A conjunctivalized corneal epithelium lacks the smoothness and cohesion of normal corneal epithelium, making it optically inferior and prone to erosions. It is also heavily vascularized. To study inflammatory response, an important component of NV, Moromizato et al. produced burn and chemical cornea model lesions by corneal cauterization or local injection into the cornea of small amounts of acid (hydrochloric acid, $0.1 \mathrm{~N}$ ) or alkali (sodium hydroxide, $0.1 \mathrm{~N}$ ) (Moromizato et al., 2000). Complex pathophysiology is a disadvantage of this model.

Animal models will continue to be needed for evaluation of safety and efficacy of combination therapies (Kim et al., 2006). Each model has strengths and weaknesses; thus, in order to gain the most useful information about the disease process and responses to therapy, the best approach may be combination of different models. Therefore, search for better, more reliable and reproducible animal models should continue.

\section{Treatment modalities}

A number of therapeutic strategies have been adopted to treat LCSD. In patients with partial limbal stem cell deficiency, mechanical debridement of the conjunctivalized epithelium can 
be performed. This prevents conjunctival epithelium from crossing the limbus and allows the corneal epithelium to heal the defect. A groundbreaking report by Kenyon and Tseng, describes case studies where autologous limbal stem cell transplantation proved to be a powerful and effective surgical procedure to restore severely damaged ocular surfaces (Kenyon and Tseng, 1989). However, in later studies, where donor tissue was harvested in a "blinded" fashion, two surgical risks were identified. First, if the donor limbal grafts do not contain adequate numbers of stem cells, the surgery will either fail immediately or lack longevity. Second, if too many stem cells are removed, the donor eye will develop problems associated with LSCD (Copeland and Char, 1990, Holland and Schwartz, 1996, Holland, 1996, Frucht-Pery et al., 1998).

\subsection{Amniotic membrane transplantation}

Human amniotic membrane (HAM) has several properties that render it extremely useful as a biomaterial for surgical purposes and it promotes epithelialization, inhibits fibrosis, has anti-inflammatory, anti-angiogenic, antimicrobial and antiviral properties, and has a high hydraulic conductivity (van Herendael et al., 1978, Gomes et al., 2005, Fernandes et al., 2005) Moreover, HAM shows low or no immunogenicity (Akle et al., 1985, Akle et al., 1981). Over the past decade, HAM's abilities to reduce scarring and inflammation, and enhance wound healing, as well as its epithelialization properties, has led to an increase in its use as a biomaterial in ophthalmic surgery, particularly for ocular surface reconstruction. HAM has also been used to promote healing in corneal diseases such as chemical and thermal burns, neurotrophic ulcers, persistent epithelial defects, shield ulcers, microbial keratitis, band keratopathy and bullous keratopathy (Dua et al., 2004, Tosi et al., 2005a, Tosi et al., 2005b). Furthermore, the use of HAM as a biomaterial has not been confined to ophthalmology - it is also widely used in general surgery and wound treatment, e.g., for burned skin, bedsores, ulcers (Faulk et al., 1980), and in head and neck surgery (Zohar et al., 1987). More recently, HAM has been used as a culture substrate for ex vivo cultured LSC transplantation.

\subsubsection{Corneal limbal autografts and allografts}

The current treatment for LSCD is limbal transplantation using auto- or allograft limbal tissues, each of which have their associated risks and benefits. In 1989, Kenyon and Tseng, treated LSCD by transplanting healthy limbal tissue on diseased limbus, procedure termed as conjunctival limbal autograft (CLAU) and living-related conjunctival limbal autograft (lrCLAL) (Kenyon and Tseng, 1989). The main disadvantage of taking limbal tissue from the patient's own contralateral healthy eye or from that of a living related donor is the risk of inducing LSCD in the donor eye, if a large amount of tissue is required (Jenkins et al., 1993). In bilateral cases with total LSCD, or in a one-eyed patient who develops total LSCD in the seeing eye, an allograft limbal transplant utilizing donor tissue from a cadaver or a living relative is the only option. A high risk of immune rejection is associated with such transplantation because of the vascularity of the limbus, the high immunogenic stimulus of the limbal transplant relative to the abundance of Langerhan's cells and HLA-DR antigens. Hence, an effective immunosuppressant is essential indefinitely or until the graft is viable. Moreover, the dosage of immunosuppression can be increased or decreased if it proves ineffective or causes adverse effects, respectively (Tseng et al., 1998, Coster et al., 1995, Santos et al., 2005). For this reason, transplantation of auto-or allograft limbal tissues is not often a viable treatment option. 


\subsubsection{Ex vivo expansion of corneal limbal stem cells}

A novel method of transplanting limbal stem cells is ex vivo expansion of LSCs. This technique is based on Rheinwald and Green's pioneering work in skin (Green et al., 1977). Skin epithelial cells have been grown successfully on a feeder layer of 3T3 fibroblasts that have been rendered mitotically inactive by irradiation or treatment with mitomycin C (Rheinwald, 1980). In the late 1990s, cultured autologous limbal epithelial cells were successfully used to improve vision in two patients with chemical injury-induced LSCD. From 1-2 $\mathrm{mm}^{2}$ limbal tissue, epithelial cells were isolated and expanded in the laboratory on tissue culture plastic, in the presence of growth-arrested 3T3 mouse fibroblast feeders, before transfer to the eye on a petrolatum gauze or a soft contact lens (Pellegrini et al., 1997). This technique has theoretical advantages over conventional treatments. Its proposed advantage over CLAU and lr-CLAL is that the required size of the limbal biopsy is substantially smaller. This minimizes the risk of precipitating stem cell failure in the donor eye and provides the option of taking a further biopsy if required.

Since 1997's landmark report, a variety of culture techniques have been developed to produce contiguous epithelial cell sheets for transplantation. These techniques can be broadly defined as either explant culture in which cells migrate out from limbal tissue attached to a surface (Grueterich et al., 2002b, Koizumi et al., 2001a, Koizumi et al., 2001b, Sangwan et al., 2006) or suspension culture in which cells are released from enzymatically digested extracellular matrix before culture (Daya et al., 2005, Nakamura et al., 2006, Pellegrini et al., 1997). The aforementioned methods have been used in studies to culture limbal epithelial cells successfully, on either a growth-arrested 3T3 fibroblast feeder layer or an amniotic membrane (AM), with varying results (Kim et al., 2004, Zito-Abbad et al., 2006).

\subsubsection{Explant culture method}

The explant culture method involves plating a whole piece of limbal tissue or limbal explant, sized approximately $1 \mathrm{~mm}$ by $1 \mathrm{~mm}$. One variation of the explant culture system uses AM, which acts as both a substrate and a carrier for the cultured cells. To attain growth from limbal explants the limbal biopsy is placed on the basement membrane surface of the amniotic membrane and allowed to adhere to it. Once attached, the biopsy and amniotic membrane are submerged in culture medium (Figure 3). This contains nutrients and mitogens that stimulate LSCs to proliferate and migrate out of the biopsy and cover the surface of the AM, which occurs over a period of 14 to 28 days.

Recently, exciting discussions have led to the question of whether or not AM epithelial cells are necessary to cultivate limbal epithelial cells. Several groups have cultured limbal epithelial cells on intact AM (AM with amniotic epithelium) and have reported that these limbal epithelial cells contained slow-cycling and label-retaining characteristic cells, which did not express corneal epithelial differentiation proteins cytokeratin 3 (CK3) or cytokeratin 12 (CK12) and connexin 43. The amniotic epithelial cells were killed by cryopreservation and then removed by enzymatic digestion, chemical treatment, or physical scraping of the membrane prior to use (Koizumi et al., 2001a, Koizumi et al., 2001b, Nakamura et al., 2004b, Sangwan et al., 2005). Grueterich et al. demonstrated that culturing LSC on amnion with intact amniotic epithelium may result in a more stem cell-like phenotype than with deepithelialized amnion (Grueterich et al., 2002b). Their study showed that, while cells on both the substrates were well attached to the AM stroma, morphologically superior, better stratified and/or differentiated limbal cells could be cultured on denuded AM compared to those cells cultured on intact AM. As a result, these studies hypothesized that denuded AM 


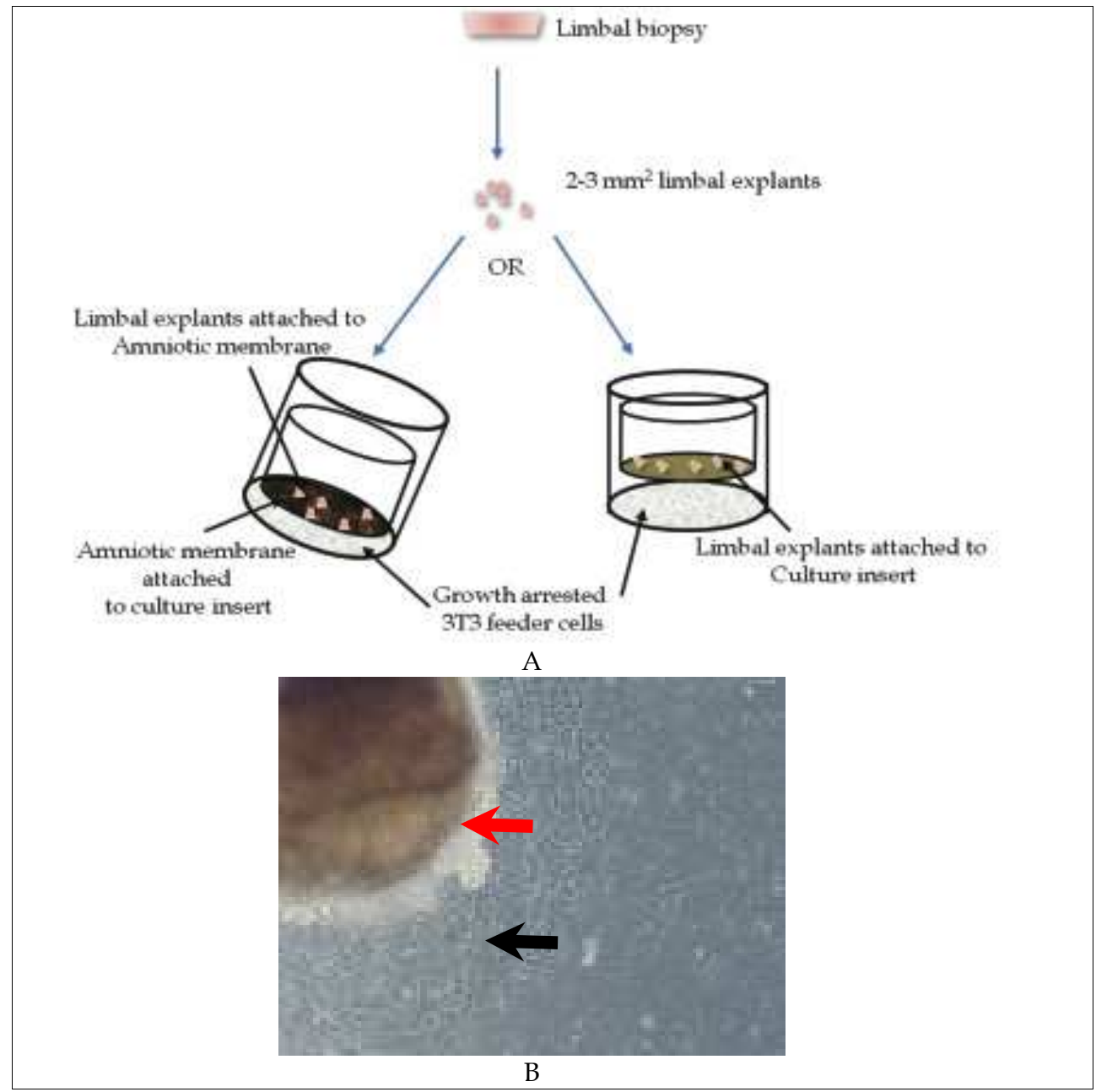

Fig. 3. The explant culture system. This method employs amniotic membrane as the carrier for cultured cells (A, Left); or cell culture insert (A-Right) as a substrate. Phase contrast micrograph reveals LSC (black arrow) migrating out of the explants (red arrow) and covering the surface of the cell culture insert over the course of 14 to 28 days (B).

is probably a more practical carrier for human limbal epithelial cell cultures in a cellsuspension culture system. Kolli et al. analyzed the outgrowths from human cadaveric limbal explants cultured on AM by dividing the explant outgrowths into three zonesinner, middle, and outer, depending on proximity to the explant. This yielded a successive decline in colony-forming efficiency (CFE), and $\triangle \mathrm{Np} 63 \mathrm{a}$ and ABCG2 expression, and an increase in expression of CK3 in zones further away from the explants. These Results support the importance of putative niche environment in maintaining the undifferentiated state of the limbal stem cells during explant outgrowth (Kolli et al., 2008). 


\subsubsection{Suspension culture system}

The cell suspension culture system employs the enzymes dispase, which digests basement membrane collagen and separates epithelial cells from the stroma, and trypsin, which separates clumps of limbal epithelial cells into a suspension of single cells (Figure 4). The single cells are then seeded either onto AM or onto a plastic tissue culture dish containing a feeder layer of growth-arrested 3T3 fibroblasts. Culture medium is then added, and the cells are incubated for 14 to 21 days. When confluent, the epithelial sheet is transferred to the ocular surface using either a contact lens or fibrin gel (Pellegrini et al., 1997, Pellegrini et al.,

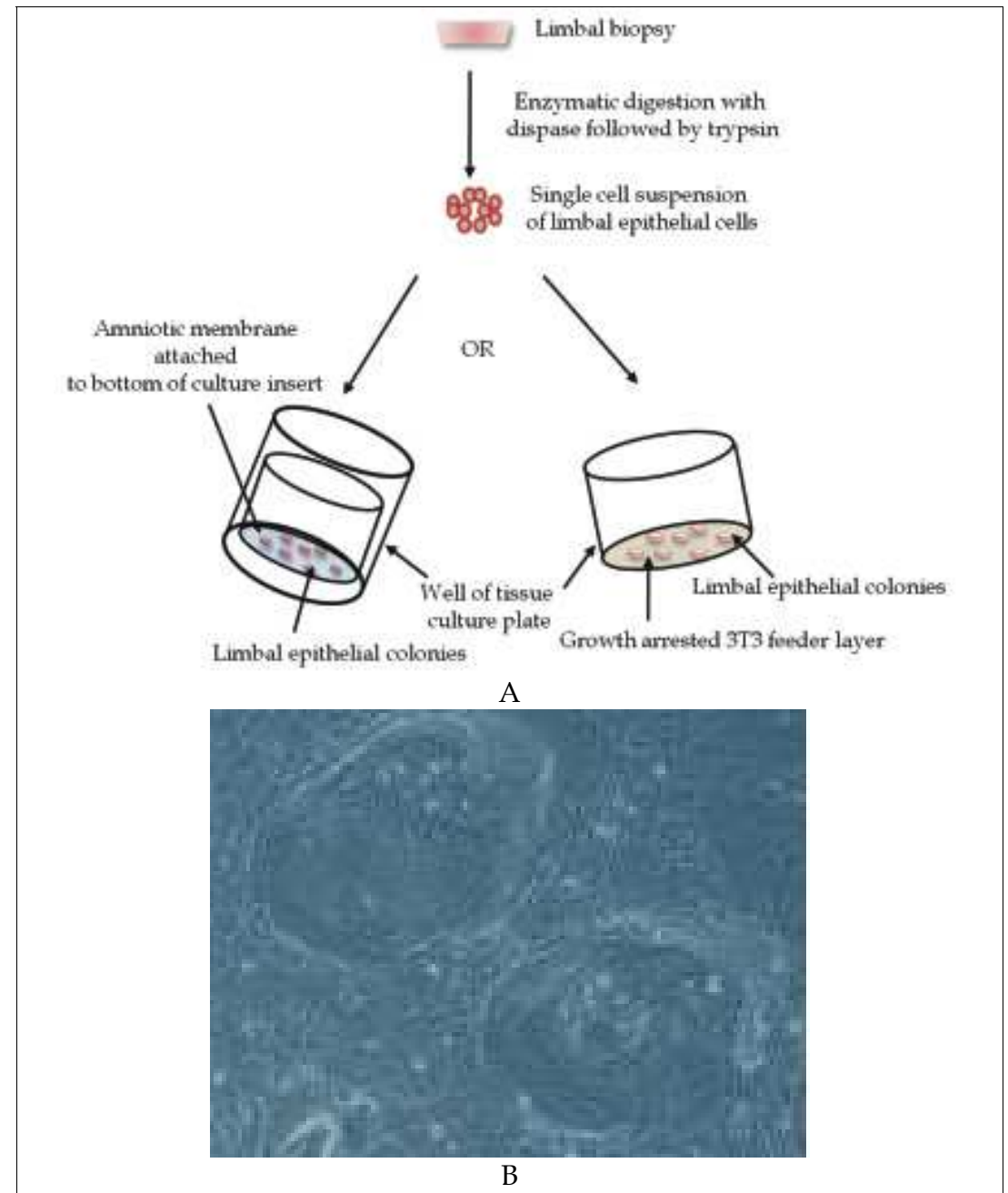

Fig. 4. The suspension culture system. This method employs the enzymes dispase and trypsin. This suspension is seeded onto either amniotic membrane (A, Left) or a plastic tissue culture dish that contains a feeder layer of growth-arrested 3T3 fibroblasts (A, Right). Phase contrast micrograph of limbal epithelial colonies on 3T3 cells (B). 
1999). Recently, Di Girolamo et al. cultured limbal epithelial cells in autologous serum, on lotrafilcon A and balafilcon A contact lenses. The cells cultured on the lotrafilcon A contact lenses proliferated, migrated, showed a corneal phenotype and microvillae on the apical surface; whereas cells cultured on balafilcon A contact lenses showed no growth (Di Girolamo et al., 2007).

Various substrates have been used in suspension culture systems for proliferation of limbal epithelial cells, for example, reconstituted collagen substrate membrane from HAM (Merrett et al., 2008), a chitosan cross-linked collagen membrane (Auxenfans et al., 2009), which has good adherence, retains epithelial morphology and supports the nontoxic nature of the membrane. Reconstituted human amniotic collagen membrane has been used to act as collagen scaffolding for the culture of limbal epithelial cells (Doillon et al., 2003, Griffith et al., 1999, Li et al., 2005). Rama et al. have provided data demonstratng that the use of fibrin as a carrier supports stem cell maintenance (Rama et al., 2001).

\subsubsection{Variations in explant and suspension cultures}

The variations in explant and cell suspension culture systems are airlifting and/or (with or without the addition) of 3T3 feeder cells. In airlifting cultures, the level of culture medium in the dish is lowered to the surface level of the epithelium, promoting stratification and differentiation of the epithelium (Ban et al., 2003, Cooper et al., 2004, Koizumi et al., 2001a, Nakamura et al., 2003b). This method can, therefore, be used for investigating the stratification and differentiation potential of cultured limbal epithelial cells with high expression of CK3 and CK12. The latter culture method, adding 3T3 feeder cells as an additional feeder layer of growth-arrested 3T3 fibroblasts in the bottom of the cell culture well is a duplex system (Miyashita et al., 2008). 3T3 fibroblasts are primitive cells isolated from embryonic mice. They have a high proliferative capacity and have been used extensively in the culture of epithelial stem cells especially in skin and cornea. Both amniotic membrane and growth-arrested 3T3 fibroblasts inhibit the differentiation of corneal epithelial cells ex vivo, which allows the expansion of the population of LSCs (Grueterich et al., 2003, Pellegrini et al., 1999). Denuded AM is thought to be an excellent substrate for the corneal limbal cell culture used for ocular surface reconstruction, even though AM epithelial cells contain various growth factors with $3 \mathrm{~T} 3$ feeder cells. This theory, however, remains to be fully investigated.

The variation in suspension culture techniques are use of novel temperature-responsive culture surfaces. Temperature-responsive polymers chemically immobilized to thin films on cell-culture surfaces facilitate cell adhesion and growth of cells in normal culture conditions, at $37^{\circ} \mathrm{C}$. Temperatures below $30^{\circ} \mathrm{C}$ can reversibly alter cell hydration properties with respect to temperature, hydration and swelling - prompting complete detachment of adherent cells without the use of proteolytic enzymes or treatment with EDTA (Nishida et al., 2004b, Nishida et al., 2004a). The advantage of this system is that no enzymes are needed to free the epithelial sheet from the culture membrane; however, application of temperature-responsive polymers in a clinical setting remains questionable for safety and efficacy.

\section{Ex vivo expansion of alternative sources of epithelium}

Although adult stem cells hold considerable promise for the treatment of a number of diseases in regenerative medicine, the second major obstacle has been to obtain sufficient number of autologous or allogeneic stem cells. 


\subsection{Oral mucosal cells}

In an attempt to overcome the problems inherent in the transplantation of allogeneic tissue, there has been recent interest in the possibility of using alternative autologous epithelial cells. There are several potential sources of non-keratinizing, stratified squamous epithelium in the adult human, including oral mucosal, conjunctival, nasal, esophageal, vaginal and rectal epithelia. The main concept is to use the smooth surface of the oral mucosa, with its stem cell properties, to reconstruct the ocular surface. Oral mucosae are thought to be at a lower stage of differentiation than epidermal keratinocytes (Collin et al., 1992, Schermer et al., 1986) because they divide rapidly and can be maintained in culture for prolonged periods without keratinization (Hata et al., 1995). Various antimicrobial peptides (AMPs) are known to be present on the epithelial cells of ocular and oral surfaces (Haynes et al., 1999). Moreover, keratin 3 is expressed by both corneal epithelium (Sangwan et al., 2003b) and oral mucosa (Collin et al., 1992, Juhl et al., 1989), suggesting that gene expression in oral and corneal epithelium may be similar. Wet-surfaced epithelia, produce a group of highly glycosylated, protective membrane glycoproteins termed mucins (Gipson, 2007). Although the function of these mucins in the oral cavity remains to be elucidated, it is possible that they contribute to the epithelial protective mucin layer and act as receptors initiating one or more intracellular signal transduction pathways (Argueso et al., 2003). At the ocular surface, at least three membrane-associated mucins (MUC1, -4, and -16) and two secreted mucins (MUC5 and -7) are expressed (Hori et al., 2007).

More extensive studies have been performed to check the feasibility of using cultivated oral mucosal epithelium (COME) for this purpose, as it is readily available and could be harvested without invasive surgery. A small biopsy of the patient's oral mucosa is harvested, connective tissue is dissected and, after enzymatic digestion, an epithelial cell suspension is prepared. The oral epithelial cells are cultivated on the substrate with a feeder layer. The sheet of cultivated cells is then transplanted onto the diseased ocular surface (Figure 5). These studies suggest that oral mucosal epithelium is a feasible alternative for

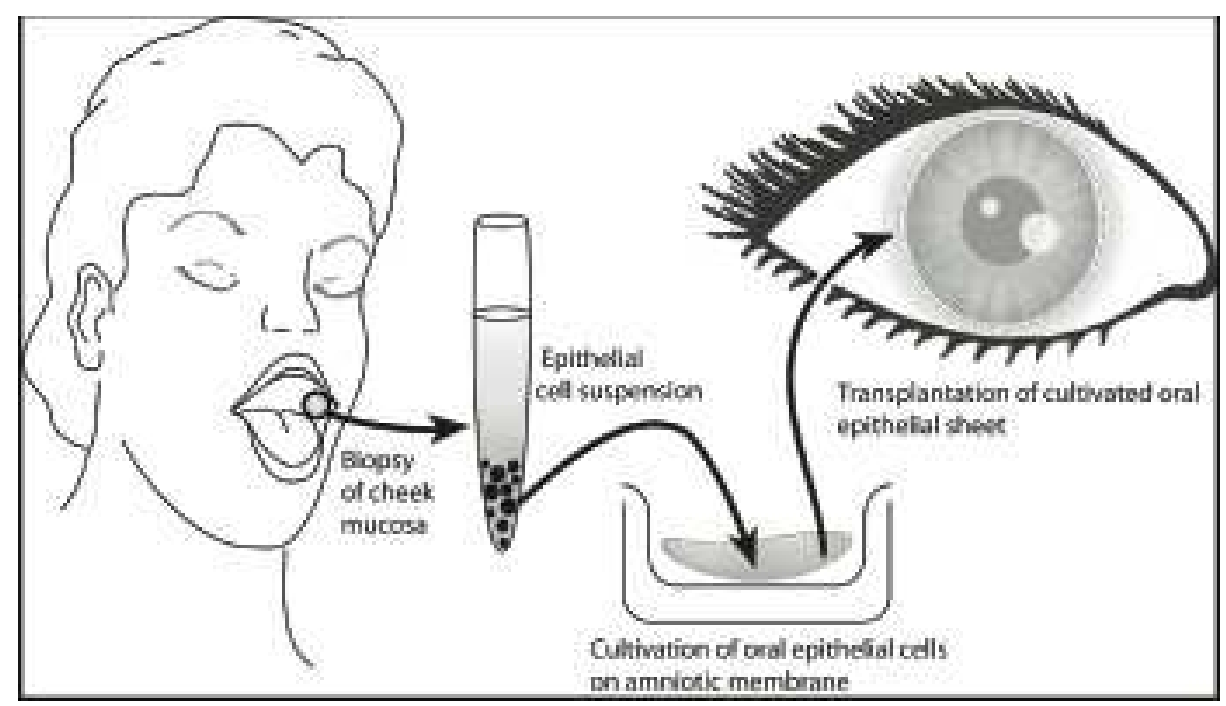

Fig. 5. Systematic representation of cultivated oral mucosal epithelium transplantation. Adopted from (Lim et al., 2009). 
allogenous limbal transplants (Nakamura et al., 2003b, Nakamura et al., 2004a, Inatomi et al., 2006, Nishida et al., 2004b, Hayashida et al., 2005). Oral mucosal epithelium cultured on human amniotic membrane with the help of feeder cells has been characterized extensively, and has been used to reconstruct the ocular surface in rabbits (Nakamura et al., 2003a) as well as humans with chemical injury and SJS (Nakamura et al., 2004a). In the lengthiest study reported so far, cultured oral mucosal epithelial cells were transplanted into patients with LSCD and followed up with for up to 34 months (Inatomi et al., 2006) where the followups continued until tissue became viable.

The main advantages of using oral mucosa are the absence of tissue rejection and, therefore, avoidance of immunosuppression; easy access to the oral cavity; inconspicuous location of the resultant small scar, and repeatability. This treatment method has not, however, provided satisfactory long-term results. The oral mucosal epithelial cell grafts seldom transdifferentiate to a corneal epithelium phenotype, e.g., expression of keratin 12 (Krt12) (Inatomi et al., 2006). This new approach, however, provides an exciting possibility for treatment of this difficult group of patients with blindness from bilateral total LSCD and warrants further study.

\subsubsection{Dental pulp stem cells}

In an attempt to prevent rejection, isolated human immature dental pulp stem cells (hIDPSC) from deciduous teeth have been used as an autologous alternative epithelium source for LSCD treatment or corneal reconstruction. hIDPSCs are known to express both mesenchymal stem cell markers (SH2, $\mathrm{SH} 3$ and $\mathrm{SH} 4)$ and human embryonic stem cell markers (OCT 4, NANOG, SSEA-3 and SSEA-4) (Gomes et al., 2010). Furthermore, hIDPSCs have a normal karyotype and show the capacity for multilineage differentiation into neurons, smooth and skeletal muscle, cartilage, bone, and other cell types ex vivo and in vivo (Kerkis et al., 2006, Lavagnolli et al., 2009). Limited studies have been performed to test dental pulp stem cells as potential treatment for LSCD. Monteiro et al. demonstrated, using immunohistochemistry and reverse transcription polymerase chain reaction, that hIDPSCs express markers in common with LSCs, such as ABCG2, integrin $\beta 1$, vimentin, p63, connexin 43 and cytokeratins 3/12. These have been shown to be capable of reconstructing the eye surface after induction of unilateral total LSCD in rabbits (Monteiro et al., 2009). Further studies are required to understand the long-term outcome of LSCD treated using hIDPSCs.

\subsubsection{Hair follicle stem cells}

Hair has the potential to regenerate from stem cells located at the lower part of the follicle called the bulge (Oshima et al., 2001). Additionally, hair follicle stem cells (HFSCs) can give rise to epidermis and sebaceous gland tissues. Recently, Blazejewska et al. demonstrated that murine HFSCs can transform into epithelia-like cells when cultured in limbal fibroblastderived medium (Blazejewska et al., 2009). Although, these findings need further substantiation using in vivo functional studies in animal models, they provide the first step towards the design of protocols that could use human autologous hair follicle stem cells to replace corneal epithelium in therapeutic applications. Due to their multipotency, easy accessibility, and high proliferation rate ex vivo, hair follicles are an attractive source of autologous adult stem cells and a promising therapeutic tool for ocular surface reconstruction. 


\subsubsection{Embryonic stem cells}

Embryonic stem cells (ESCs) are pluripotent (i.e., they can give rise to any cell type in the body) and are derived from the inner cell mass of a blastocyst. Differentiation of ESCs to a corneal epithelial lineage could be achieved by replication of the LSC niche environment. Transplantation of epithelial cells derived from mouse ESCs have been used to reconstruct chemically injured mouse corneas (Homma et al., 2004). Moreover, human ESCs express cornea-like epithelial markers such as CK3 and CK12 when cultured in conditions similar to those of the limbal stem cell niche. Ex vivo replication of the LSC niche environment has been achieved by culturing hESCs on an extracellular matrix of collagen IV and fed with medium conditioned with limbal fibroblasts (Ahmad et al., 2007). The differentiated human ESCs demonstrate phenotypic differences to cultured human limbal epithelial cells, such as differences in size and cilia length, which are characteristically much longer than those of limbal epithelial cells. These data suggest that some differences exist between LSCs and hESCderived corneal progenitors (Ahmad et al., 2007). The translation of this approach to human therapeutic use requires further work to overcome problems associated with functionality, complete hESC differentiation and immune rejection as well as ethical concerns.

\section{Future considerations for cultivated epithelial transplants}

Ex vivo expansion of limbal epithelium has been performed by several unrelated groups in a number of countries and used to treat a variety of ocular surface disorders that are thought to be the result of limbal stem cell failure. Despite a substantial number of experimental models of this technique and an ever-growing body of laboratory data on limbal epithelial stem cell biology, scientific basis for this procedure is poorly understood. Future considerations in the field of limbal epithelial cell culture and transplantation methods are discussed below.

\subsection{Culture methodologies}

The culture of limbal epithelium is essential for furthering our understanding of limbal stem cell biology. Ex vivo expansion of LSCs for the treatment of LSCD is one of the more recent stem cell treatments available in the field of regenerative medicine. Although the technique of ex vivo expansion of LSCs is still in its infancy, it is starting to be used by several groups for clinical purposes, and different approaches have been attempted. There are many varying techniques for culturing limbal epithelial cells, such as different media and sera; culture with 3T3 fibroblasts or amniotic membrane, or both; removal of amniotic membrane epithelial cells from the membrane, or not; use of explant or suspension methods; and airlifting of the culture, or not (Shortt et al., 2007, Grueterich et al., 2003). Whichever culture method is used, the end result, often after a period of weeks, is a cultivated epithelial sheet composed of LSCs. The ease of explanting culture technique could be adapted without initial dispase treatment for transplantation studies. However, further studies on the interaction between epithelial progenitor and autologous stromal cells ex vivo, and complete characterization of limbal cells in this culture system, including cell junction proteins, are required.

\subsubsection{Autologous sources and xenobiotic-free conditions}

With growing concerns regarding the potential transmission of opportunistic agents such as prions and animal viruses, it would be preferable to culture cells for human transplantation 
under xenobiotic-free conditions. In limbal corneal epithelial cultures, the use of autologous human serum in the medium and/or human amniotic membrane would be appropriate as it would reduce the need for animal cells or products in the culture (Kolli et al., 2010, Nakamura et al., 2004a, Nakamura et al., 2006). To avoid contamination from xeno-feeder layers, different human feeder layers have also been developed and analyzed (Chen et al., 2007). Moreover, cells have been cultured on feeder layers during the proliferative phase and further separated using robotic technology (Schneider et al., 2008). Limbal epithelial cells grown with MRC-5 human embryonic fibroblasts can sustain the stem cell phenotype (Notara et al., 2007). The successful use of autologous serum-derived oral epithelial equivalent to treat severe ocular surface disease was reported in 2006 (Ang et al., 2006, Nakamura et al., 2006). This represents an important advance in the pursuit of completely autologous xenobiotic-free bioengineered ocular equivalents for clinical transplantation.

In conclusion, a specific culture system that mimics natural tissue architecture and its niche closely by enabling formation of an autofeeder layer, thereby eliminating the need for xenofeeder layers for ex vivo expansion of epithelial progenitor cells is important.

\subsubsection{Combination techniques with anti-angiogenic treatments}

Angiogenic and anti-angiogenic cytokines are involved in cell migration and differentiation in wound healing and tumor progression (even in the absence of angiogenesis). The everincreasing use of anti-angiogenic therapy for corneal neovascularization brings great promise for the treatment of a wide variety of corneal conditions, including LSCD. TGF- $\beta$, IL-1, and VEGF are the key pro-angiogenic factors involved in the process of angiogenesis; and are targets for anti-angiogenic therapies. The ultimate goal for research on corneal angiogenesis is to discover effective treatment for pathological corneal neovascularization; however, to date, most anti-angiogenic therapies remain experimental.

Angiostatin, a $38 \mathrm{kDa}$ proteolytic fragment of plasminogen, is a potent anti-angiogenic factor. Recombinant angiostatin has been used successfully to suppress tumor growth and metastasis in animal model systems (Shin et al., 2000, Ambati et al., 2002). Gabison and associates have demonstrated the involvement of angiostatin in corneal avascularity after wounding. They confirmed that angiostatin-like molecules are expressed in the corneal epithelium and in cultured corneal epithelial cells (Gabison et al., 2004). Corneal neovascularization was observed after excimer laser keratectomy when anti-angiostatin antibodies were injected into the cornea; this was significantly higher than when plasmin B chain antibodies were injected. These studies suggest that angiostatin may contribute to the maintenance of corneal avascularity after excimer laser keratectomy.

The corneal epithelium may be the source of anti-angiogenic molecules. It has long been demonstrated that corneal epithelium inhibits angiogenesis (Kaminski and Kaminska, 1978). Ferreras and associates demonstrated the generation of endostatin-like fragments by cleaving collagen XVIII with MMP-2, -3, -9, -12, -13, or -14 (Ferreras et al., 2000). Upregulation of matrix-derived anti-angiogenic factors such as endostatin (Kato et al., 2003) and restin (Saika et al., 2004), along with increased anti-inflammatory factor IL-1ra may play an important role in LSC and AM transplantation-mediated anti-angiogenic effect. Recently, Cursiefen et al. demonstrated a critical mechanism that contributed to corneal avascularity by VEGF receptor 3, which is normally present on lymphatic and proliferating blood vascular endothelium, is strongly constitutively expressed by corneal epithelium and is mechanistically responsible for suppressing inflammatory corneal angiogenesis (Cursiefen et al., 2006). Knowledge gained from using epithelia-matrix interaction to regulate corneal 
angiogenesis will enable us to optimize the anti-angiogenic effect of the cultivated cells like oral mucosal epithelial cells or mesehchymal stem cells for future ocular surface reconstruction.

\section{Clinical trials and outcomes: present and future}

LSCD by any cause may result in poor corneal epithelialization, persistent epithelial defects, corneal vascularization, corneal scarring, and so-called conjunctivalization of the cornea. These problems may in turn lead to decreased vision, ocular discomfort and pain, as well as an unstable ocular surface. Limbal stem cells may be partially or totally depleted, resulting in varying degrees of stem cell deficiency and resulting abnormalities on the corneal surface. The first use of ex vivo expanded LSCs for the treatment of LSCD in human subjects was described by Pellegrini and co-workers, who used a culture system of LSCs grown on mouse J2-3T3 fibroblasts with fetal calf serum (FCS) supplemented media (Pellegrini et al., 1997). Since then, several studies have been reported on the transplantation of ex vivo cultured LSCs to treat LSCD (Schwab et al., 2000, Tsai et al., 2000, Koizumi et al., 2001b, Grueterich et al., 2002a). Schwab et al. reported the results of treating 19 eyes of 18 patients (Schwab, 1999). In 2003, Sangwan et al. reported the largest study to date, which enrolled 125 patients (Sangwan et al., 2003b). In this study ex vivo cultured limbal and conjunctival epithelial cells were grown on AM. In 2006, Sangwan et al. published a more detailed report on clinical outcomes for 88 eyes of 86 patients (Sangwan et al., 2006). In 2001, Rama et al. reported treatment outcomes for 18 eyes of 18 patients (Rama et al., 2001). The same group recently reported a 10 year follow-up with permanent restoration of transparent corneal epithelium in $76.6 \%$ of eyes, with few 63 instances of inflammation out of 113 eyes treated (Rama et al., 2010). The outcome of cultured limbal stem cells transplants differed significantly depending on whether the transplanted cultures contained more than 3\% p63-bright holoclone-forming stem cells or 3\% or less - the success rates were $78 \%$ with the larger number of stem cells and $11 \%$ increase with the smaller number of p63 cells (Rama et al., 2001, Rama et al., 2010), suggesting the importance of a high percentage of p63 in cultured limbal stem cells. The remaining studies each treated between 2 and 14 patients (Kolli et al., 2010, Grueterich et al., 2002b, Nakamura et al., 2004a, Sangwan et al., 2003a).

In total, current studies reported data to enable analysis of outcomes in 506 eyes (Baylis et al., 2011) treated using ex vivo, cultured LSC transplants and 27 eyes treated with ex vivo cultured oral mucosal epithelium. To date, the limited periods (mean follow-up was 16.74 months, median 14 months, range 6 to 29.5 months), the use of subjective outcome measures, and the absence of a reliable method for detecting transplanted (stem) cells shows that a long term success rate has yet to be established.

Ex vivo expansion and transplantation of limbal epithelium have been performed by several unrelated groups in a number of countries, with uncertainty in the limbal stem cell cultivation, with different variables, including source of donor limbal tissue, culture method (e.g., suspension versus explant culture), culture composition (e.g., 3T3 fibroblasts, amniotic membrane and fibrin), and variation in culture time. Overall the success rate for cultured limbal epithelial transplantation is $76 \%$. This is based on clinical restoration of the corneal epithelium. It is interesting that, despite the different methodologies employed, the success rates and number of significant clinical outcomes are remarkably high. It would, therefore, appear that, as long as viable limbal epithelial stem cells are transferred, the method used to achieve this is relatively unimportant. 
The future directions in LSC transplantation involve modifications of existing technologies to allow improved safety and efficacy of techniques at hand. The studies on the molecular mechanism of limbal stem cells and their niche will enhance our knowledge of how cell therapy can be further modified to closely mimic in vivo conditions. Identification of key niche factors controlling limbal stem cell behaviour would allow these conditions to replicate ex vivo and, thus, make the process of culturing limbal stem cells safer and more efficient. Newly developed transplantation techniques using tissue-engineered epidermal adult stem cells, immature dental pulp stem cells (Gomes et al., 2010), and hair follicle bulgederived stem cells (Blazejewska et al., 2009) were reportedly successful for the reconstruction of corneal epithelium in an animal model of severe LSCD. The recombinant human crosslinked collagen scaffold and a Food and Drug Administration-approved contact lens are also promising new techniques for successfully achieving ocular surface reconstruction (Di Girolamo et al., 2007). There are main challenges in improving the established techniques, in elimination of animal-derived products and minimization of allogeneic human tissue use. Since cell-based therapies are being scrutinized by ever-increasing regulatory requirements, many investigators that have been successfully performing ex vivo cultivation in the past are reformulating their methodologies to conform to these guidelines (Daniels et al., 2006, Kolli et al., 2010). The future of this methodology lies in the standardization of the stem cell preparation and cultivation techniques with clearly defined endpoints and outcome measures of treatment success.

\section{Acknowledgment}

We would like to thank Ms. Sandhya M. Sharma (Schepens Eye Research Institute, Harvard University) for providing human limbus cross section in Figure 1 (B).

\section{References}

Ahmad, S., Stewart, R., Yung, S., et al. (2007) Differentiation of human embryonic stem cells into corneal epithelial-like cells by in vitro replication of the corneal epithelial stem cell niche, Stem Cells, 25, 1145-55.

Akle, C., McColl, I., Dean, M., et al. (1985) Transplantation of amniotic epithelial membranes in patients with mucopolysaccharidoses, Exp Clin Immunogenet, 2, 43-8.

Akle, C. A., Adinolfi, M., Welsh, K. I., et al. (1981) Immunogenicity of human amniotic epithelial cells after transplantation into volunteers, Lancet, 2, 1003-5.

Alessandri, G., Raju, K. and Gullino, P. M. (1983) Mobilization of capillary endothelium in vitro induced by effectors of angiogenesis in vivo, Cancer Res, 43, 1790-7.

Amano, S., Rohan, R., Kuroki, M., et al. (1998) Requirement for vascular endothelial growth factor in wound- and inflammation-related corneal neovascularization, Invest Ophthalmol Vis Sci, 39, 18-22.

Ambati, B. K., Joussen, A. M., Ambati, J., et al. (2002) Angiostatin inhibits and regresses corneal neovascularization, Arch Ophthalmol, 120, 1063-8.

Ang, L. P., Nakamura, T., Inatomi, T., et al. (2006) Autologous serum-derived cultivated oral epithelial transplants for severe ocular surface disease, Arch Ophthalmol, 124, 154351.

Argueso, P., Spurr-Michaud, S., Russo, C. L., et al. (2003) MUC16 mucin is expressed by the human ocular surface epithelia and carries the H185 carbohydrate epitope, Invest Ophthalmol Vis Sci, 44, 2487-95. 
Auxenfans, C., Builles, N., Andre, V., et al. (2009) [Porous matrix and primary-cell culture: a shared concept for skin and cornea tissue engineering], Pathol Biol (Paris), 57, 290-8.

Ban, Y., Cooper, L. J., Fullwood, N. J., et al. (2003) Comparison of ultrastructure, tight junction-related protein expression and barrier function of human corneal epithelial cells cultivated on amniotic membrane with and without air-lifting, Exp Eye Res, 76, 735-43.

Barouch, F. C. and Miller, J. W. (2006) Potential future targets for treating ocular neovascularization, Ophthalmol Clin North Am, 19, 401-9.

Barros, E. J., Santos, O. F., Matsumoto, K., et al. (1995) Differential tubulogenic and branching morphogenetic activities of growth factors: implications for epithelial tissue development, Proc Natl Acad Sci U S A, 92, 4412-6.

Baylis, O., Figueiredo, F., Henein, C., et al. (2011) 13 years of cultured limbal epithelial cell therapy: a review of the outcomes, J Cell Biochem, 112, 993-1002.

Berger, O., Gan, X., Gujuluva, C., et al. (1999) CXC and CC chemokine receptors on coronary and brain endothelia, Mol Med, 5, 795-805.

Biswas, P. S., Banerjee, K., Kinchington, P. R. and Rouse, B. T. (2006) Involvement of IL-6 in the paracrine production of VEGF in ocular HSV-1 infection, Exp Eye Res, 82, 46-54.

Blazejewska, E. A., Schlotzer-Schrehardt, U., Zenkel, M., et al. (2009) Corneal limbal microenvironment can induce transdifferentiation of hair follicle stem cells into corneal epithelial-like cells, Stem Cells, 27, 642-52.

Bron, A. J. (1973) Vortex patterns of the corneal epithelium, Trans Ophthalmol Soc U K, 93, 455-72.

Chang, J. H., Gabison, E. E., Kato, T. and Azar, D. T. (2001) Corneal neovascularization, Curr Opin Ophthalmol, 12, 242-9.

Chen, Y. T., Li, W., Hayashida, Y., et al. (2007) Human amniotic epithelial cells as novel feeder layers for promoting ex vivo expansion of limbal epithelial progenitor cells, Stem Cells, 25, 1995-2005.

Collin, C., Ouhayoun, J. P., Grund, C. and Franke, W. W. (1992) Suprabasal marker proteins distinguishing keratinizing squamous epithelia: cytokeratin 2 polypeptides of oral masticatory epithelium and epidermis are different, Differentiation, 51, 137-48.

Cooper, L. J., Fullwood, N. J., Koizumi, N., et al. (2004) An investigation of removed cultivated epithelial transplants in patients after allocultivated corneal epithelial transplantation, Cornea, 23, 235-42.

Copeland, R. A., Jr. and Char, D. H. (1990) Limbal autograft reconstruction after conjunctival squamous cell carcinoma, Am J Ophthalmol, 110, 412-5.

Coster, D. J., Aggarwal, R. K. and Williams, K. A. (1995) Surgical management of ocular surface disorders using conjunctival and stem cell allografts, Br J Ophthalmol, 79, 977-82.

Cotsarelis, G., Cheng, S. Z., Dong, G., et al. (1989) Existence of slow-cycling limbal epithelial basal cells that can be preferentially stimulated to proliferate: implications on epithelial stem cells, Cell, 57, 201-9.

Cursiefen, C., Chen, L., Saint-Geniez, M., et al. (2006) Nonvascular VEGF receptor 3 expression by corneal epithelium maintains avascularity and vision, Proc Natl Acad Sci U S A, 103, 11405-10.

Daniels, J. T., Secker, G. A., Shortt, A. J., et al. (2006) Stem cell therapy delivery: treading the regulatory tightrope, Regen $\mathrm{Med}, 1,715-9$. 
Davanger, M. and Evensen, A. (1971) Role of the pericorneal papillary structure in renewal of corneal epithelium, Nature, 229, 560-1.

Daya, S. M., Watson, A., Sharpe, J. R., et al. (2005) Outcomes and DNA analysis of ex vivo expanded stem cell allograft for ocular surface reconstruction, Ophthalmology, 112, 470-7.

Deutsch, T. A. and Hughes, W. F. (1979) Suppressive effects of indomethacin on thermally induced neovascularization of rabbit corneas, Am J Ophthalmol, 87, 536-40.

Dhanabal, M., Ramchandran, R., Waterman, M. J., et al. (1999) Endostatin induces endothelial cell apoptosis, J Biol Chem, 274, 11721-6.

Di Girolamo, N., Chui, J., Wakefield, D. and Coroneo, M. T. (2007) Cultured human ocular surface epithelium on therapeutic contact lenses, Br J Ophthalmol, 91, 459-64.

Doillon, C. J., Watsky, M. A., Hakim, M., et al. (2003) A collagen-based scaffold for a tissue engineered human cornea: physical and physiological properties, Int J Artif Organs, 26, 764-73.

Dua, H. S. (1998) The conjunctiva in corneal epithelial wound healing, Br J Ophthalmol, 82, 1407-11.

Dua, H. S. and Forrester, J. V. (1990) The corneoscleral limbus in human corneal epithelial wound healing, Am J Ophthalmol, 110, 646-56.

Dua, H. S., Gomes, J. A., King, A. J. and Maharajan, V. S. (2004) The amniotic membrane in ophthalmology, Surv Ophthalmol, 49, 51-77.

Dua, H. S., Saini, J. S., Azuara-Blanco, A. and Gupta, P. (2000) Limbal stem cell deficiency: concept, aetiology, clinical presentation, diagnosis and management, Indian J Ophthalmol, 48, 83-92.

Fatima, A., Iftekhar, G., Sangwan, V. S. and Vemuganti, G. K. (2008) Ocular surface changes in limbal stem cell deficiency caused by chemical injury: a histologic study of excised pannus from recipients of cultured corneal epithelium, Eye (Lond), 22, 11617.

Faulk, W. P., Matthews, R., Stevens, P. J., et al. (1980) Human amnion as an adjunct in wound healing, Lancet, 1, 1156-8.

Fernandes, M., Sridhar, M. S., Sangwan, V. S. and Rao, G. N. (2005) Amniotic membrane transplantation for ocular surface reconstruction, Cornea, 24, 643-53.

Ferreras, M., Felbor, U., Lenhard, T., et al. (2000) Generation and degradation of human endostatin proteins by various proteinases, FEBS Lett, 486, 247-51.

Frucht-Pery, J., Siganos, C. S., Solomon, A., et al. (1998) Limbal cell autograft transplantation for severe ocular surface disorders, Graefes Arch Clin Exp Ophthalmol, 236, 582-7.

Fuchs, E., Tumbar, T. and Guasch, G. (2004) Socializing with the neighbors: stem cells and their niche, Cell, 116, 769-78.

Fujishima, H., Shimazaki, J. and Tsubota, K. (1996) Temporary corneal stem cell dysfunction after radiation therapy, $\mathrm{Br}$ J Ophthalmol, 80, 911-4.

Gabison, E., Chang, J. H., Hernandez-Quintela, E., et al. (2004) Anti-angiogenic role of angiostatin during corneal wound healing, Exp Eye Res, 78, 579-89.

Gimbrone, M. A., Jr., Cotran, R. S., Leapman, S. B. and Folkman, J. (1974) Tumor growth and neovascularization: an experimental model using the rabbit cornea, J Natl Cancer Inst, 52, 413-27.

Gipson, I. K. (1989) The epithelial basement membrane zone of the limbus, Eye (Lond), 3 ( Pt 2), 132-40. 
Gipson, I. K. (2007) The ocular surface: the challenge to enable and protect vision: the Friedenwald lecture, Invest Ophthalmol Vis Sci, 48, 4390; 4391-8.

Goede, V., Brogelli, L., Ziche, M. and Augustin, H. G. (1999) Induction of inflammatory angiogenesis by monocyte chemoattractant protein-1, Int J Cancer, 82, 765-70.

Goldberg, M. F. and Bron, A. J. (1982) Limbal palisades of Vogt, Trans Am Ophthalmol Soc, $80,155-71$.

Gomes, J. A., Geraldes Monteiro, B., Melo, G. B., et al. (2010) Corneal reconstruction with tissue-engineered cell sheets composed of human immature dental pulp stem cells, Invest Ophthalmol Vis Sci, 51, 1408-14.

Gomes, J. A., Romano, A., Santos, M. S. and Dua, H. S. (2005) Amniotic membrane use in ophthalmology, Curr Opin Ophthalmol, 16, 233-40.

Grant, W. M. and Kern, H. L. (1955) Action of alkalies on the corneal stroma, AMA Arch Ophthalmol, 54, 931-9.

Green, H., Rheinwald, J. G. and Sun, T. T. (1977) Properties of an epithelial cell type in culture: the epidermal keratinocyte and its dependence on products of the fibroblast, Prog Clin Biol Res, 17, 493-500.

Griffith, M., Osborne, R., Munger, R., et al. (1999) Functional human corneal equivalents constructed from cell lines, Science, 286, 2169-72.

Grueterich, M., Espana, E. and Tseng, S. C. (2002a) Connexin 43 expression and proliferation of human limbal epithelium on intact and denuded amniotic membrane, Invest Ophthalmol Vis Sci, 43, 63-71.

Grueterich, M., Espana, E. M., Touhami, A., et al. (2002b) Phenotypic study of a case with successful transplantation of ex vivo expanded human limbal epithelium for unilateral total limbal stem cell deficiency, Ophthalmology, 109, 1547-52.

Grueterich, M., Espana, E. M. and Tseng, S. C. (2003) Ex vivo expansion of limbal epithelial stem cells: amniotic membrane serving as a stem cell niche, Surv Ophthalmol, 48, 631-46.

Hanai, J., Gloy, J., Karumanchi, S. A., et al. (2002) Endostatin is a potential inhibitor of Wnt signaling, J Cell Biol, 158, 529-39.

Hata, K., Kagami, H., Ueda, M., et al. (1995) The characteristics of cultured mucosal cell sheet as a material for grafting; comparison with cultured epidermal cell sheet, Ann Plast Surg, 34, 530-8.

Hayashida, Y., Nishida, K., Yamato, M., et al. (2005) Ocular surface reconstruction using autologous rabbit oral mucosal epithelial sheets fabricated ex vivo on a temperature-responsive culture surface, Invest Ophthalmol Vis Sci, 46, 1632-9.

Haynes, R. J., Tighe, P. J. and Dua, H. S. (1999) Antimicrobial defensin peptides of the human ocular surface, Br J Ophthalmol, 83, 737-41.

Holland, E. J. (1996) Epithelial transplantation for the management of severe ocular surface disease, Trans Am Ophthalmol Soc, 94, 677-743.

Holland, E. J. and Schwartz, G. S. (1996) The evolution of epithelial transplantation for severe ocular surface disease and a proposed classification system, Cornea, 15, 54956.

Homma, R., Yoshikawa, H., Takeno, M., et al. (2004) Induction of epithelial progenitors in vitro from mouse embryonic stem cells and application for reconstruction of damaged cornea in mice, Invest Ophthalmol Vis Sci, 45, 4320-6.

Hori, Y., Sugiyama, H., Soma, T. and Nishida, K. (2007) Expression of membrane-associated mucins in cultivated human oral mucosal epithelial cells, Cornea, 26, S65-9. 
Huang, A. J. and Tseng, S. C. (1991) Corneal epithelial wound healing in the absence of limbal epithelium, Invest Ophthalmol Vis Sci, 32, 96-105.

Inatomi, T., Nakamura, T., Koizumi, N., et al. (2006) Midterm results on ocular surface reconstruction using cultivated autologous oral mucosal epithelial transplantation, Am J Ophthalmol, 141, 267-275.

Jeng, B. H., Halfpenny, C. P., Meisler, D. M. and Stock, E. L. (2011) Management of focal limbal stem cell deficiency associated with soft contact lens wear, Cornea, 30, 18-23.

Jenkins, C., Tuft, S., Liu, C. and Buckley, R. (1993) Limbal transplantation in the management of chronic contact-lens-associated epitheliopathy, Eye (Lond), 7 ( Pt 5), 629-33.

Juhl, M., Reibel, J. and Stoltze, K. (1989) Immunohistochemical distribution of keratin proteins in clinically healthy human gingival epithelia, Scand J Dent Res, 97, 159-70.

Kaminski, M. and Kaminska, G. (1978) Inhibition of lymphocyte-induced angiogenesis by enzymatically isolated rabbit cornea cells, Arch Immunol Ther Exp (Warsz), 26, 107982.

Karakousis, P. C., John, S. K., Behling, K. C., et al. (2001) Localization of pigment epithelium derived factor (PEDF) in developing and adult human ocular tissues, Mol Vis, 7, 154-63.

Kato, T., Chang, J. H. and Azar, D. T. (2003) Expression of type XVIII collagen during healing of corneal incisions and keratectomy wounds, Invest Ophthalmol Vis Sci, 44, 78-85.

Kenyon, K. R. and Tseng, S. C. (1989) Limbal autograft transplantation for ocular surface disorders, Ophthalmology, 96, 709-22; discussion 722-3.

Kerkis, I., Kerkis, A., Dozortsev, D., et al. (2006) Isolation and characterization of a population of immature dental pulp stem cells expressing OCT-4 and other embryonic stem cell markers, Cells Tissues Organs, 184, 105-16.

Kim, H. S., Jun Song, X., de Paiva, C. S., et al. (2004) Phenotypic characterization of human corneal epithelial cells expanded ex vivo from limbal explant and single cell cultures, Exp Eye Res, 79, 41-9.

Kim, I. K., Husain, D., Michaud, N., et al. (2006) Effect of intravitreal injection of ranibizumab in combination with verteporfin PDT on normal primate retina and choroid, Invest Ophthalmol Vis Sci, 47, 357-63.

Kim, Y. M., Jang, J. W., Lee, O. H., et al. (2000) Endostatin inhibits endothelial and tumor cellular invasion by blocking the activation and catalytic activity of matrix metalloproteinase, Cancer Res, 60, 5410-3.

Klenkler, B. and Sheardown, H. (2004) Growth factors in the anterior segment: role in tissue maintenance, wound healing and ocular pathology, Exp Eye Res, 79, 677-88.

Klenkler, B. J., Griffith, M., Becerril, C., et al. (2005) EGF-grafted PDMS surfaces in artificial cornea applications, Biomaterials, 26, 7286-96.

Koch, A. E., Polverini, P. J., Kunkel, S. L., et al. (1992) Interleukin-8 as a macrophage-derived mediator of angiogenesis, Science, 258, 1798-801.

Koizumi, N., Inatomi, T., Suzuki, T., et al. (2001a) Cultivated corneal epithelial stem cell transplantation in ocular surface disorders, Ophthalmology, 108, 1569-74.

Koizumi, N., Inatomi, T., Suzuki, T., et al. (2001b) Cultivated corneal epithelial transplantation for ocular surface reconstruction in acute phase of Stevens-Johnson syndrome, Arch Ophthalmol, 119, 298-300. 
Kolli, S., Ahmad, S., Lako, M. and Figueiredo, F. (2010) Successful clinical implementation of corneal epithelial stem cell therapy for treatment of unilateral limbal stem cell deficiency, Stem Cells, 28, 597-610.

Kolli, S., Lako, M., Figueiredo, F., et al. (2008) Loss of corneal epithelial stem cell properties in outgrowths from human limbal explants cultured on intact amniotic membrane, Regen Med, 3, 329-42.

Korey, M., Peyman, G. A. and Berkowitz, R. (1977) The effect of hypertonic ointments on corneal alkali burns, Ann Ophthalmol, 9, 1383-7.

Lavagnolli, T. M., Fonseca, S. A., Serafim, R. C., et al. (2009) Presumptive germ cells derived from mouse pluripotent somatic cell hybrids, Differentiation, 78, 124-30.

Lavker, R. M., Tseng, S. C. and Sun, T. T. (2004) Corneal epithelial stem cells at the limbus: looking at some old problems from a new angle, Exp Eye Res, 78, 433-46.

Li, D. Q., Chen, Z., Song, X. J., et al. (2005) Partial enrichment of a population of human limbal epithelial cells with putative stem cell properties based on collagen type IV adhesiveness, Exp Eye Res, 80, 581-90.

Lim, P., Fuchsluger, T. A. and Jurkunas, U. V. (2009) Limbal stem cell deficiency and corneal neovascularization, Semin Ophthalmol, 24, 139-48.

Loughman, M. S., Chatzistefanou, K., Gonzalez, E. M., et al. (1996) Experimental corneal neovascularisation using sucralfate and basic fibroblast growth factor, Aust $N$ Z J Ophthalmol, 24, 289-95.

McCulley, J. P. (1990) Ocular hydrofluoric acid burns: animal model, mechanism of injury and therapy, Trans Am Ophthalmol Soc, 88, 649-84.

McCulley, J. P., Whiting, D. W., Petitt, M. G. and Lauber, S. E. (1983) Hydrofluoric acid burns of the eye, J Occup Med, 25, 447-50.

Merrett, K., Fagerholm, P., McLaughlin, C. R., et al. (2008) Tissue-engineered recombinant human collagen-based corneal substitutes for implantation: performance of type I versus type III collagen, Invest Ophthalmol Vis Sci, 49, 3887-94.

Miyashita, H., Higa, K., Kato, N., et al. (2007) Hypoxia enhances the expansion of human limbal epithelial progenitor cells in vitro, Invest Ophthalmol Vis Sci, 48, 3586-93.

Miyashita, H., Shimmura, S., Higa, K., et al. (2008) A novel NIH/3T3 duplex feeder system to engineer corneal epithelial sheets with enhanced cytokeratin 15-positive progenitor populations, Tissue Eng Part A, 14, 1275-82.

Monteiro, B. G., Serafim, R. C., Melo, G. B., et al. (2009) Human immature dental pulp stem cells share key characteristic features with limbal stem cells, Cell Prolif, 42, 587-94.

Moromizato, Y., Stechschulte, S., Miyamoto, K., et al. (2000) CD18 and ICAM-1-dependent corneal neovascularization and inflammation after limbal injury, Am J Pathol, 157, 1277-81.

Morrison, S. J., Shah, N. M. and Anderson, D. J. (1997) Regulatory mechanisms in stem cell biology, Cell, 88, 287-98.

Mukhopadhyay, M., Gorivodsky, M., Shtrom, S., et al. (2006) Dkk2 plays an essential role in the corneal fate of the ocular surface epithelium, Development, 133, 2149-54.

Nakamura, T., Endo, K., Cooper, L. J., et al. (2003a) The successful culture and autologous transplantation of rabbit oral mucosal epithelial cells on amniotic membrane, Invest Ophthalmol Vis Sci, 44, 106-16.

Nakamura, T., Inatomi, T., Sotozono, C., et al. (2004a) Transplantation of cultivated autologous oral mucosal epithelial cells in patients with severe ocular surface disorders, Br J Ophthalmol, 88, 1280-4. 
Nakamura, T., Inatomi, T., Sotozono, C., et al. (2006) Transplantation of autologous serumderived cultivated corneal epithelial equivalents for the treatment of severe ocular surface disease, Ophthalmology, 113, 1765-72.

Nakamura, T., Inatomi, T., Sotozono, C., et al. (2004b) Successful primary culture and autologous transplantation of corneal limbal epithelial cells from minimal biopsy for unilateral severe ocular surface disease, Acta Ophthalmol Scand, 82, 468-71.

Nakamura, T., Koizumi, N., Tsuzuki, M., et al. (2003b) Successful regrafting of cultivated corneal epithelium using amniotic membrane as a carrier in severe ocular surface disease, Cornea, 22, 70-1.

Nishida, K., Yamato, M., Hayashida, Y., et al. (2004a) Functional bioengineered corneal epithelial sheet grafts from corneal stem cells expanded ex vivo on a temperatureresponsive cell culture surface, Transplantation, 77, 379-85.

Nishida, K., Yamato, M., Hayashida, Y., et al. (2004b) Corneal reconstruction with tissueengineered cell sheets composed of autologous oral mucosal epithelium, $N$ Engl J Med, 351, 1187-96.

Notara, M., Haddow, D. B., MacNeil, S. and Daniels, J. T. (2007) A xenobiotic-free culture system for human limbal epithelial stem cells, Regen Med, 2, 919-27.

Oshima, H., Rochat, A., Kedzia, C., et al. (2001) Morphogenesis and renewal of hair follicles from adult multipotent stem cells, Cell, 104, 233-45.

Pellegrini, G., Golisano, O., Paterna, P., et al. (1999) Location and clonal analysis of stem cells and their differentiated progeny in the human ocular surface, J Cell Biol, 145, 769-82.

Pellegrini, G., Traverso, C. E., Franzi, A. T., et al. (1997) Long-term restoration of damaged corneal surfaces with autologous cultivated corneal epithelium, Lancet, 349, 990-3.

Pfister, R. R. (1994) Corneal stem cell disease: concepts, categorization, and treatment by auto- and homotransplantation of limbal stem cells, Clao J, 20, 64-72.

Puangsricharern, V. and Tseng, S. C. (1995) Cytologic evidence of corneal diseases with limbal stem cell deficiency, Ophthalmology, 102, 1476-85.

Rama, P., Bonini, S., Lambiase, A., et al. (2001) Autologous fibrin-cultured limbal stem cells permanently restore the corneal surface of patients with total limbal stem cell deficiency, Transplantation, 72, 1478-85.

Rama, P., Matuska, S., Paganoni, G., et al. (2010) Limbal stem-cell therapy and long-term corneal regeneration, $N$ Engl J Med, 363, 147-55.

Ramchandran, R., Dhanabal, M., Volk, R., et al. (1999) Antiangiogenic activity of restin, NC10 domain of human collagen XV: comparison to endostatin, Biochem Biophys Res Commun, 255, 735-9.

Rheinwald, J. G. (1980) Serial cultivation of normal human epidermal keratinocytes, Methods Cell Biol, 21A, 229-54.

Rogers, M. S., Birsner, A. E. and D'Amato, R. J. (2007) The mouse cornea micropocket angiogenesis assay, Nat Protoc, 2, 2545-50.

Romano, A. C., Espana, E. M., Yoo, S. H., et al. (2003) Different cell sizes in human limbal and central corneal basal epithelia measured by confocal microscopy and flow cytometry, Invest Ophthalmol Vis Sci, 44, 5125-9.

Saika, S., Okada, Y., Miyamoto, T., et al. (2004) Protein expression pattern of collagen type XV in mouse cornea, Graefes Arch Clin Exp Ophthalmol, 242, 432-6.

Sangwan, V. S., Matalia, H. P., Vemuganti, G. K., et al. (2006) Clinical outcome of autologous cultivated limbal epithelium transplantation, Indian J Ophthalmol, 54, 29-34. 
Sangwan, V. S., Murthy, S. I., Vemuganti, G. K., et al. (2005) Cultivated corneal epithelial transplantation for severe ocular surface disease in vernal keratoconjunctivitis, Cornea, 24, 426-30.

Sangwan, V. S., Vemuganti, G. K., Iftekhar, G., et al. (2003a) Use of autologous cultured limbal and conjunctival epithelium in a patient with severe bilateral ocular surface disease induced by acid injury: a case report of unique application, Cornea, 22, 47881.

Sangwan, V. S., Vemuganti, G. K., Singh, S. and Balasubramanian, D. (2003b) Successful reconstruction of damaged ocular outer surface in humans using limbal and conjuctival stem cell culture methods, Biosci Rep, 23, 169-74.

Santos, M. S., Gomes, J. A., Hofling-Lima, A. L., et al. (2005) Survival analysis of conjunctival limbal grafts and amniotic membrane transplantation in eyes with total limbal stem cell deficiency, Am J Ophthalmol, 140, 223-30.

Schermer, A., Galvin, S. and Sun, T. T. (1986) Differentiation-related expression of a major $64 \mathrm{~K}$ corneal keratin in vivo and in culture suggests limbal location of corneal epithelial stem cells, J Cell Biol, 103, 49-62.

Schlotzer-Schrehardt, U., Dietrich, T., Saito, K., et al. (2007) Characterization of extracellular matrix components in the limbal epithelial stem cell compartment, Exp Eye Res, 85, 845-60.

Schneider, A., Spitkovsky, D., Riess, P., et al. (2008) "The good into the pot, the bad into the crop!"--a new technology to free stem cells from feeder cells, PLoS One, 3, e3788.

Schwab, I. R. (1999) Cultured corneal epithelia for ocular surface disease, Trans Am Ophthalmol Soc, 97, 891-986.

Schwab, I. R., Reyes, M. and Isseroff, R. R. (2000) Successful transplantation of bioengineered tissue replacements in patients with ocular surface disease(1), Am J Ophthalmol, 130, 543-4.

Shimmura, S., Miyashita, H., Higa, K., et al. (2006) Proteomic analysis of soluble factors secreted by limbal fibroblasts, Mol Vis, 12, 478-84.

Shin, S. H., Kim, J. C., Chang, S. I., et al. (2000) Recombinant kringle 1-3 of plasminogen inhibits rabbit corneal angiogenesis induced by angiogenin, Cornea, 19, 212-7.

Shortt, A. J., Secker, G. A., Munro, P. M., et al. (2007) Characterization of the limbal epithelial stem cell niche: novel imaging techniques permit in vivo observation and targeted biopsy of limbal epithelial stem cells, Stem Cells, 25, 1402-9.

Sotozono, C., Kinoshita, S., Kita, M. and Imanishi, J. (1994) Paracrine role of keratinocyte growth factor in rabbit corneal epithelial cell growth, Exp Eye Res, 59, 385-91.

Soubrane, G., Jerdan, J., Karpouzas, I., et al. (1990) Binding of basic fibroblast growth factor to normal and neovascularized rabbit cornea, Invest Ophthalmol Vis Sci, 31, 323-33.

Stoltz, R. A. and Schwartzman, M. L. (1997) High affinity binding sites for 12(R)Hydroxyeicosatrienoic acid [12(R)-HETrE] in microvessel endothelial cells, J Ocul Pharmacol Ther, 13, 191-9.

Strieter, R. M., Kunkel, S. L., Elner, V. M., et al. (1992) Interleukin-8. A corneal factor that induces neovascularization, Am J Pathol, 141, 1279-84.

Takahashi, T., Kalka, C., Masuda, H., et al. (1999) Ischemia- and cytokine-induced mobilization of bone marrow-derived endothelial progenitor cells for neovascularization, Nat Med, 5, 434-8. 
Tao, Y., Bazan, H. E. and Bazan, N. G. (1995) Platelet-activating factor induces the expression of metalloproteinases-1 and -9 , but not -2 or -3 , in the corneal epithelium, Invest Ophthalmol Vis Sci, 36, 345-54.

Tao, Y., Bazan, H. E. and Bazan, N. G. (1996) Platelet-activating factor enhances urokinasetype plasminogen activator gene expression in corneal epithelium, Invest Ophthalmol Vis Sci, 37, 2037-46.

Ti, S. E., Grueterich, M., Espana, E. M., et al. (2004) Correlation of long term phenotypic and clinical outcomes following limbal epithelial transplantation cultivated on amniotic membrane in rabbits, Br J Ophthalmol, 88, 422-7.

Tosi, G. M., Massaro-Giordano, M., Caporossi, A. and Toti, P. (2005a) Amniotic membrane transplantation in ocular surface disorders, J Cell Physiol, 202, 849-51.

Tosi, G. M., Traversi, C., Schuerfeld, K., et al. (2005b) Amniotic membrane graft: histopathological findings in five cases, J Cell Physiol, 202, 852-7.

Townsend, W. M. (1991) The limbal palisades of Vogt, Trans Am Ophthalmol Soc, 89, 721-56.

Tsai, R. J., Li, L. and Chen, J. (2000) Reconstruction of damaged corneas by transplantation of autologous limbal epithelial cells(1), Am J Ophthalmol, 130, 543.

Tseng, S. C. (1985) Staging of conjunctival squamous metaplasia by impression cytology, Ophthalmology, 92, 728-33.

Tseng, S. C. (1989) Concept and application of limbal stem cells, Eye (Lond), 3 ( Pt 2), 141-57.

Tseng, S. C. (1996) Regulation and clinical implications of corneal epithelial stem cells, Mol Biol Rep, 23, 47-58.

Tseng, S. C., Prabhasawat, P., Barton, K., et al. (1998) Amniotic membrane transplantation with or without limbal allografts for corneal surface reconstruction in patients with limbal stem cell deficiency, Arch Ophthalmol, 116, 431-41.

van Herendael, B. J., Oberti, C. and Brosens, I. (1978) Microanatomy of the human amniotic membranes. A light microscopic, transmission, and scanning electron microscopic study, Am J Obstet Gynecol, 131, 872-80.

Vaporciyan, A. A., DeLisser, H. M., Yan, H. C., et al. (1993) Involvement of plateletendothelial cell adhesion molecule-1 in neutrophil recruitment in vivo, Science, 262, 1580-2.

Wilson, S. E., He, Y. G., Weng, J., et al. (1994) Effect of epidermal growth factor, hepatocyte growth factor, and keratinocyte growth factor, on proliferation, motility and differentiation of human corneal epithelial cells, Exp Eye Res, 59, 665-78.

Yoshida, S., Ono, M., Shono, T., et al. (1997) Involvement of interleukin-8, vascular endothelial growth factor, and basic fibroblast growth factor in tumor necrosis factor alpha-dependent angiogenesis, Mol Cell Biol, 17, 4015-23.

Zito-Abbad, E., Borderie, V. M., Baudrimont, M., et al. (2006) Corneal epithelial cultures generated from organ-cultured limbal tissue: factors influencing epithelial cell growth, Curr Eye Res, 31, 391-9.

Zohar, Y., Talmi, Y. P., Finkelstein, Y., et al. (1987) Use of human amniotic membrane in otolaryngologic practice, Laryngoscope, 97, 978-80. 


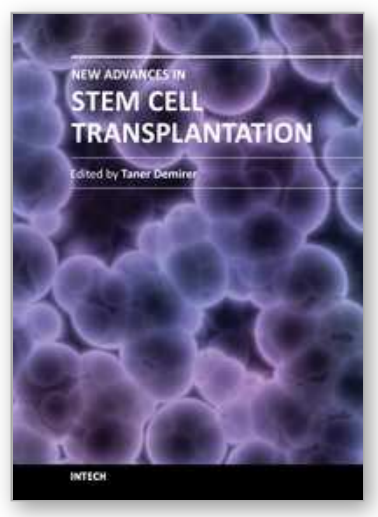

\author{
New Advances in Stem Cell Transplantation \\ Edited by Prof. Taner Demirer
}

ISBN 978-953-51-0013-3

Hard cover, 582 pages

Publisher InTech

Published online 24, February, 2012

Published in print edition February, 2012

This book documents the increased number of stem cell-related research, clinical applications, and views for the future. The book covers a wide range of issues in cell-based therapy and regenerative medicine, and includes clinical and preclinical chapters from the respected authors involved with stem cell studies and research from around the world. It complements and extends the basics of stem cell physiology, hematopoietic stem cells, issues related to clinical problems, tissue typing, cryopreservation, dendritic cells, mesenchymal cells, neuroscience, endovascular cells and other tissues. In addition, tissue engineering that employs novel methods with stem cells is explored. Clearly, the continued use of biomedical engineering will depend heavily on stem cells, and this book is well positioned to provide comprehensive coverage of these developments.

\title{
How to reference
}

In order to correctly reference this scholarly work, feel free to copy and paste the following:

Kishore Reddy Katikireddy and Jurkunas V. Ula (2012). Limbal Stem Cell Transplantation and Corneal Neovascularization, New Advances in Stem Cell Transplantation, Prof. Taner Demirer (Ed.), ISBN: 978-95351-0013-3, InTech, Available from: http://www.intechopen.com/books/new-advances-in-stem-celltransplantation/limbal-stem-cell-deficiency-and-corneal-neovascularization

\section{INTECH}

open science | open minds

\section{InTech Europe}

University Campus STeP Ri

Slavka Krautzeka 83/A

51000 Rijeka, Croatia

Phone: +385 (51) 770447

Fax: +385 (51) 686166

www.intechopen.com

\author{
InTech China \\ Unit 405, Office Block, Hotel Equatorial Shanghai \\ No.65, Yan An Road (West), Shanghai, 200040, China \\ 中国上海市延安西路65号上海国际贵都大饭店办公楼 405 单元 \\ Phone: +86-21-62489820 \\ Fax: +86-21-62489821
}


(C) 2012 The Author(s). Licensee IntechOpen. This is an open access article distributed under the terms of the Creative Commons Attribution 3.0 License, which permits unrestricted use, distribution, and reproduction in any medium, provided the original work is properly cited. 